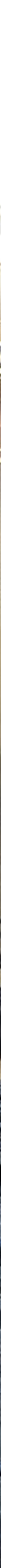





\section{Nordic Shipyards}

Best Available Techniques (BAT)

Esa Salminen, Jan Holmegaard Hansen, Claus Werner Nielsen and Paula Wuokko

TemaNord 2016:548 


\section{Nordic Shipyards}

Best Available Techniques (BAT)

Esa Salminen, Jan Holmegaard Hansen, Claus Werner Nielsen and

Paula Wuokko

ISBN 978-92-893-4731-0 (PRINT)

ISBN 978-92-893-4732-7 (PDF)

ISBN 978-92-893-4733-4 (EPUB)

http://dx.doi.org/10.6027/TN2016-548

TemaNord 2016:548

ISSN 0908-6692

Standard: PDF/UA-1

ISO 14289-1

(c) Nordic Council of Ministers 2016

Layout: Hanne Lebech

Cover photo: Turku Repair Yard Ltd

Print: Rosendahls-Schultz Grafisk

Printed in Denmark

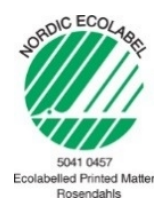

Although the Nordic Council of Ministers funded this publication, the contents do not necessarily reflect its views, policies or recommendations.

\section{Nordic co-operation}

Nordic co-operation is one of the world's most extensive forms of regional collaboration, involving Denmark, Finland, Iceland, Norway, Sweden, the Faroe Islands, Greenland, and Åland.

Nordic co-operation has firm traditions in politics, the economy, and culture. It plays an important role in European and international collaboration, and aims at creating a strong Nordic community in a strong Europe.

Nordic co-operation seeks to safeguard Nordic and regional interests and principles in the global community. Shared Nordic values help the region solidify its position as one of the world's most innovative and competitive. 


\section{Contents}

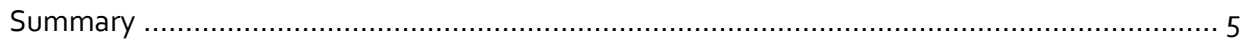

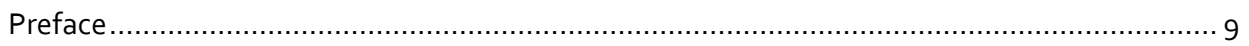

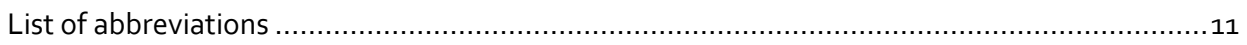

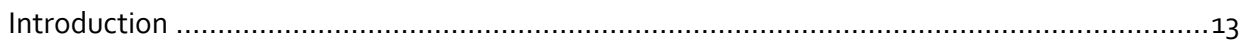

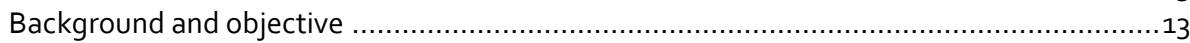

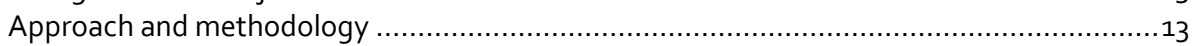

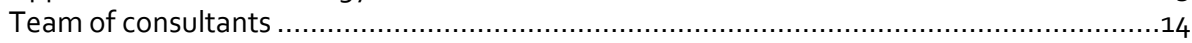

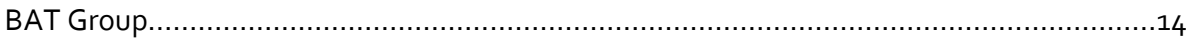

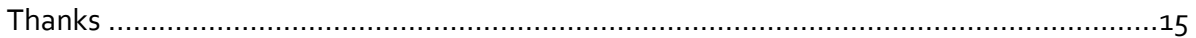

1. Shipyard activities in the Nordic countries and the used techniques ..............................17

1.1 Shipyard activities in the Nordic countries ..................................................... 17

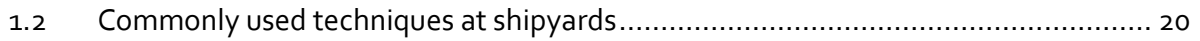

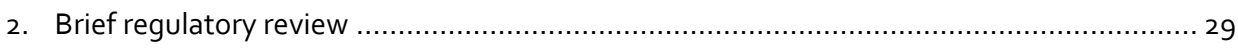

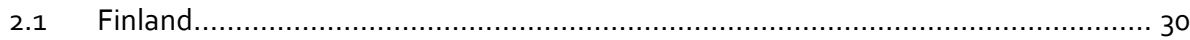

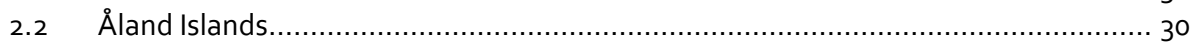

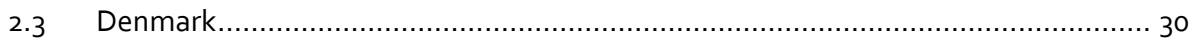

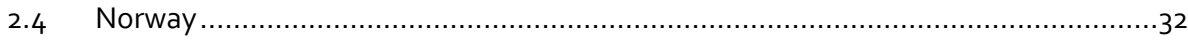

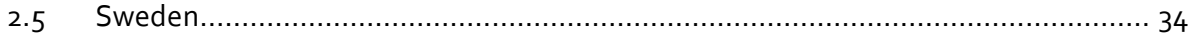

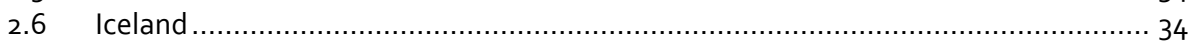

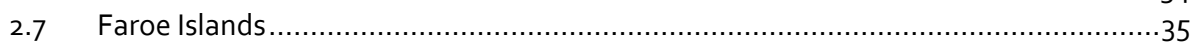

3. Environmental impacts from shipyards and key environmental indicators (KEI) ................37

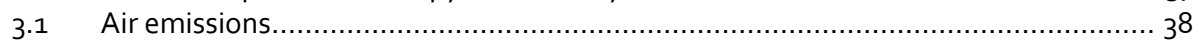

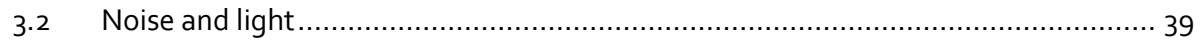

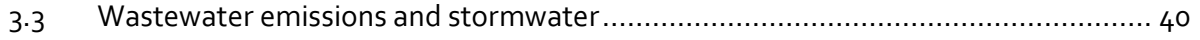

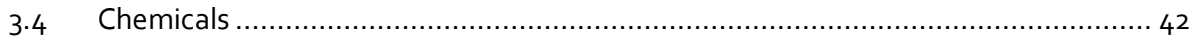

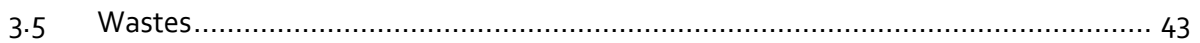

3.6 Contamination of soil, groundwater, sea, lake water and sediment ...................... 44

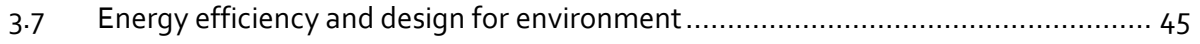

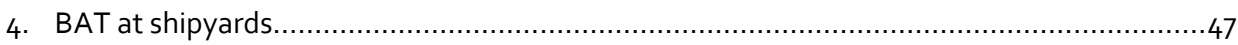

4.1 BAT for environmental management, including monitoring and reporting .............47

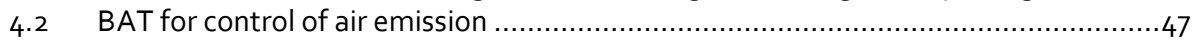

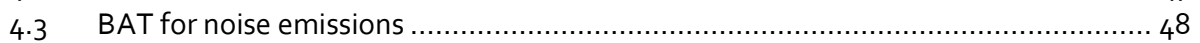

4.4 BAT for control of wastewater and stormwater emissions ................................ 48

4.5 BAT for chemicals handling and substitution ............................................. 49

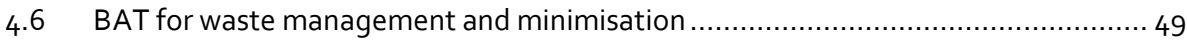

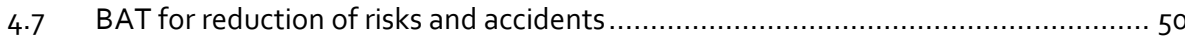

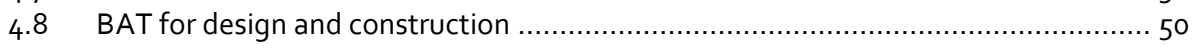

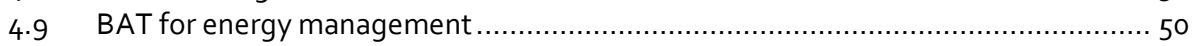




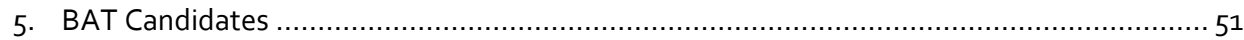

5.1 BAT Candidate no. 1 - Ultra High Pressure water blasting (UHP blasting)............... 52

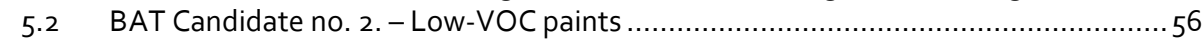

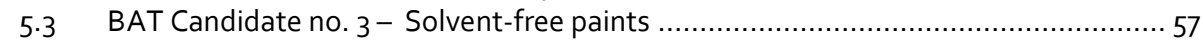

5.4 BAT Candidate no. 4 - Waterborne paints in shipbuilding ................................ 59

5.5 BAT Candidate no. 5- Fully or partially enclosed facilities for surface treatment .....60

5.6 BAT Candidate no. 6 - Multi-functional wastewater treatment facilities ..................63

5.7 BAT Candidate no. 7 - Environmental Management Systems (EMS) .....................67

5.8 BAT Candidate no. 8 - Environmentally friendly construction and operation of docks

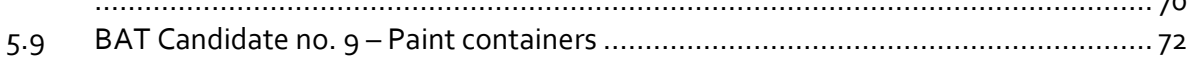

5.10 BAT Candidate no. 10 - Environmentally friendly underwater hull and propeller

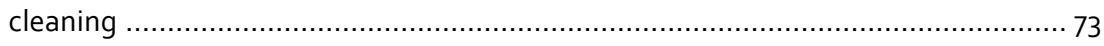

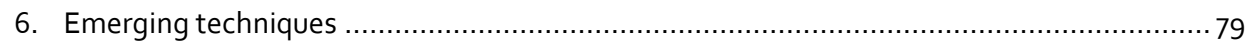

6.1 Paint removal from ship hull by induction heating by laser ................................ 79

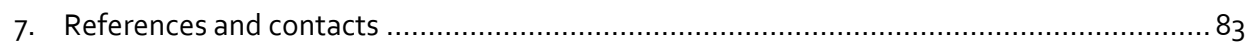

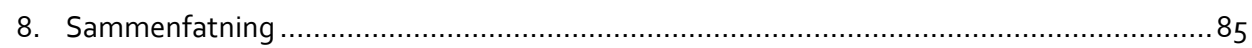




\section{Summary}

The BAT Group of the Nordic Council of Ministers has decided to conduct a project on Best Available Techniques (BAT) for the shipyards in the Nordic countries. The objectives of the project have been to:

- Review and describe the shipyard sector in the Nordic countries.

- Review and describe the used techniques in the Nordic countries.

- Identify and describe the Key Environmental Indicators from the Nordic perspective.

- Identify and describe techniques that shall be included in the considerations of representing BAT in shipyards.

The scope of the project has included steel ships, but not ships built of wood or reinforced plastic. The focus has been on surface treatment in relation to maintenance and repair, and also to a minor extent shipbuilding, but not demolition, handling of ballast water or engine maintenance and repair.

The provided information can be utilised by operators, environmental consultants and competent environmental authorities. The projects might also be usable as a Nordic input for the Technical Working Group in the revision of the BAT conclusions for the "Surface Treatment Using Organic Solvents (STS)" according to the Industrial Emission Directive (IED).

Shipbuilding has a long tradition and it has previously been a large industry in all the Nordic countries. Today ships are maintained and repaired at many shipyards in all the Nordic countries. On the other hand, shipbuilding takes place only at a limited number of shipyards.

Environmental impacts from shipyards in the Nordic countries are different due to a number of reasons, which are, among others:

- Impacts from shipbuilding differ a lot from repair and maintenance.

- Different facilities like dry docks, floating docks and slipways of different sizes have different possibilities to prevent emissions; some shipyards are older and not 
equipped with technical arrangements to handle emissions (like barriers and wastewater treatment facilities), which can be difficult to be installed afterwards.

- Different sizes of ships.

- Different climatic conditions (temperature, tide, snowfall etc.).

- Site settings (some shipyards are located in cities or towns close to residential areas or close to nature protected areas).

The key environmetal indicators (KEI) in the scope of this study are (in nonprioritised order):

- Air emissions (dust and volatile organic compounds (VOC)).

- Noise emission.

- Wastewater emissions and stormwater (hazardous substances such as heavy metals and oils).

- Wastes (steel in shipbuilding and blasting material with hazardous substances in repair and maintenance).

- Chemicals (paints and antifouling agents).

- Contamination of soil, groundwater and sea and lake water and sediment.

- Energy efficiency and design for environment (shipbuilding).

Presented BAT at shipyards describes:

- BAT for environmental management, including monitoring and reporting.

- BAT for control of air emission.

- BAT for noise emissions.

- BAT for control of wastewater and stormwater emissions.

- BAT for chemical handling and substitution.

- BAT for waste management and minimization.

- BAT for reduction of risks and accidents.

- BAT for design and construction.

- BAT for energy management. 
Technical and economic applicability as well as environmental impacts of BAT varies a lot, being very much case dependent. It is also noteworthy that the selection of techniques is not always in the hands of the shipyard. The ship owner or paint manufacturer often determine the paints to be used and requirements for the surface preparation before painting. Presented BAT candidates are listed in Table 1.

Table 1: BAT candidates

\section{No BAT Candidate}

Ultra high pressure water blasting (UHP blasting)

Low VOC paints

Solvent-free paints

Waterborne paints in shipbuilding

Fully or partially enclosed facilities for surface treatment

Multi-functional wastewater treatment facilities

Environmental management systems (EMS)

Environmentally friendly construction and operation of docks

Paint containers

Environmentally friendly underwater hull and propeller cleaning

Paint removal from ship hull by induction heating with laser is presented as an emerging technology. We are not aware of this technology today being used in Nordic shipyards. Existing applications are special purposes where the coating to be removed is particularly thick. 



\section{Preface}

The Nordic Council of Ministers, the BAT Group under the Working Group for sustainable consumption and production (also called HKP) Group has requested Vahanen Environment Oy, Finland together with COWI AS, Denmark to prepare a Best Available Techniques (BAT) project at shipyards in the Nordic countries.

The provided information can be utilised by operators, environmental consultants and competent environmental authorities. The projects might also be usable as a Nordic input for the Technical Working Group in the revision of the BAT conclusions for the "Surface Treatment Using Organic Solvents (STS)" according to the Industrial Emission Directive (IED).

Ten potential BAT candidates and an emerging technique are included in the report which address measures to reduce air emissions, noise emission, wastewater discharge and production of waste at shipyards.

The following consultants have contributed to the report:

Core team:

- Esa Salminen, Vahanen Environment Oy (Project Manager).

- Jan Holmegaard Hansen, COWI A/S.

Support team:

- Claus Werner Nielsen, COWI A/S.

- Paula Wuokko, Vahanen Environment Oy.

The BAT project has been followed and commented on by the Nordic BAT Group. The members of the BAT Group are:

- Halla Einarsdóttir, Environment Agency of Iceland.

- Anne Katrine Arnesen, Norwegian Environment Agency, Norway.

- Kaj Forsius, Finnish Environment Institute. 
- Lena Ziskason, Environment Agency of the Faroe Islands.

- Susanne Särs, Environmental and Health Protection Agency of the Åland Islands.

- Birgitte Holm Christensen, Danish Environmental Protection Agency.

- Annika Månsson, Swedish Environmental Protection Agency. 


\section{List of abbreviations}

$\mathrm{AVI}$

BAT Group

BAT

BREF document

ELY Centres

EMS

IED

IMO

$\mathrm{KEI}$

LNG

STS

UHP blasting

VOC

ÅMHM
Regional State Administrative Agencies in Finland.

BAT Group is a sub-group of the Working Group for Sustainable Consumption and Production.

Best Available Techniques.

Best Available Technology Reference Document.

The Centres for Economic Development, Transport and the Environment in Finland.

Environmental management systems.

The Industrial Emissions Directive (2010/75/EU).

The International Maritime Organization.

Key environmetal indicators.

Liquefied natural gas.

Surface Treatment Using Organic Solvents.

Ultra high pressure blasting.

Volatile organic compounds.

The environmental and health protection agency of Åland. 



\title{
Introduction
}

\author{
Background and objective
}

The BAT Group of the Nordic Council of Ministers has decided to conduct a Nordic BAT project on shipyards in the Nordic countries.

The objectives of the project have been to:

- Review and describe the shipyard sector in the Nordic countries.

- Review and describe the used techniques in the sector.

- Identify and describe the Key Environmental Indicators from a Nordic perspective.

- Identify and describe techniques, which shall be included in the considerations of representing Best Available Techniques (BAT) in shipyards.

The previous Nordic BAT report for shipyards was published as a Tema-Nord 1996:556 document with the title: Reduction of Emissions from Ship Yards.

The scope of the project has included steel ships, but not ships built of wood or reinforced plastic. The focus has been on surface treatment in relation to maintenance and repair, and also to a minor extent to shipbuilding, but not demolition, handling of ballast water or engine maintenance and repair.

The provided information can be utilised by operators, environmental consultants and competent environmental authorities. The project might also be usable as a Nordic input for the Technical Working Group in the revision of the BAT conclusions for the "Surface Treatment Using Organic Solvents (STS)" according to the Industrial Emission Directive (IED).

\section{Approach and methodology}

Information and data on shipyards, used techniques and emissions was collected Nordic-wide from documents and by contacts supplemented by visits to a number of shipyards. Shipyards of different sizes using different types of equipment and building and repairing different types of ships were contacted in order to establish the broad- 
est possible project coverage. The focus of the project was on maintenance and repair, which is more common than shipbuilding in the Nordic countries. Furthermore, suppliers and other stakeholders, such as the Nordic associations of shipyards, paint and equipment manufacturers were contacted.

When identifying the BAT candidates, first a long list of them was developed. The shortlist of BAT candidates was then prioritised from the long list according to the following priorities:

- BAT, which addresses the identified Key Environmental Indicators.

- BAT, which is assessed to have a significant reduction of emission and impacts.

- BAT, which is economically and technically viable taking into consideration the cost and advantages.

- BAT, which primarily is developed or has its origin in the Nordic countries.

\section{Team of consultants}

The following consultants have contributed to the report:

Core team:

- Esa Salminen, Vahanen Environment Oy (Project Manager).

- Jan Holmegaard Hansen, COWI A/S.

Support team:

- Claus Werner Nielsen, COWI A/S.

- Paula Wuokko, Vahanen Environment Oy.

\section{BAT Group}

The BAT project has been followed and commented on by the Nordic BAT Group. The members of the BAT Group are:

- Halla Einarsdóttir, Environment Agency of Iceland. 
- Anne Katrine Arnesen, Norwegian Environment Agency, Norway.

- Kaj Forsius, Finnish Environment Institute.

- Lena Ziskason, Environment Agency of the Faroe Islands.

- Susanne Särs, Environmental and Health Protection Agency of the Åland Islands.

- Birgitte Holm Christensen, Danish Environmental Protection Agency.

- Annika Månsson, Swedish Environmental Protection Agency.

\section{Thanks}

The team of consultants hereby expresses our sincere thanks to the client and all companies, associations and persons who have contributed to the report. A special thanks to the companies that have taken time to see the consultants and for all the valuable data and information that the team has received. Without this support, it would not have been possible to reach the expected outcome. 



\section{Shipyard activities in the Nordic countries and the used techniques}

\subsection{Shipyard activities in the Nordic countries}

Shipbuilding has a long tradition and it has previously been a large industry in all the Nordic countries. During recent decades the industry sector has changed a lot. Already for decades, European shipyards have been facing strong global competition and today shipbuilding takes place only at a limited number of shipyards. On the other hand, maintenance and repair take place at a large number of medium and small-sized shipyards and they have consequently a much more important role environmentally in the Nordic countries, which has also been the main focus of this study. Nordic repair shipyards are facing competition from shipyards in the Baltic countries and Poland. Price competition with the shipyards is hard, although also quality of work matters.

This chapter briefly describes the industry sector in the different Nordic countries country by country.

\subsubsection{Finland}

In Finland, shipbuilding has a more important role compared to that in the other Nordic countries. Finnish shipyards manufacture many special deliveries, such as floating, deep-sea Spar-type oil platforms and offshore equipment related to wind power, and many types of supply vessels as well as Oasis-class cruise ships.

Finnish marine industries consist of shipyards and a broad network of companies, such as design offices, turnkey companies, material and system providers, and the offshore industry. The annual turnover of the field is around 5.4 billion euros and it employs 20,000 persons. More than 90\% of products are exported.

Meyer Turku, Arctech Helsinki and Uki Workboat in Uusikaupunki are examples of shipbuilding shipyards and Turku Repair Yard in Naantali and Western Shipyard in Teijo of repair and maintenance shipyards. The Suomenlinna repair yard, dating back to 1750, is one of the oldest in Europe still in operation. Technip in Pori produces various kinds of projects, newbuilding and conversions. The newest company is Rauma Ma- 
rine Constructions, established to operate in the Rauma shipyard, which also has a long history of operation.

Finnish equipment manufacturers have many innovative products, such as environmentally friendly liquefied natural gas (LNG) fuelled engines, advanced propulsion systems for energy efficiency, as well as the Hi-Fog fire protection system, which extinguishes fires with water mist. Among the best known are companies such as ABB Finland, Aalborg Industries, Cargotec, Evac, Helkama Bica, Koja, Marioff, Metos and Wärtsilä.

Finnish design offices offer a wide variety of consulting, design, research and development services, as well as software for the design and operation of ships.

\subsection{2 Åland Islands}

In the Åland Islands there are two relatively small repair yards, in Möckelö harbour and Marienhamn.

\subsubsection{Denmark}

Denmark has traditionally had a significant shipbuilding industry. During the 80 and 9os, all larger shipyards were closed.

Today, 12 mid-sized shipyards and docks are building a limited number of small and medium-size ships, offshore installations, special ships, and doing ship conversions. Some yards have been bought by other yards, reducing the total number.

Shipyards are today mainly dealing with repair and maintenance activities.

Some shipyards are working closely together with the suppliers to the sector, and even cluster cooperation has been established in the Northern part of Denmark.

Most importantly, environmental impacts today are from repair and maintenance activites.

\subsubsection{Faroe Islands}

In the Faroe Islands, there are five shipyards mainly for repair and maintenance.

MEST Shipyard is an old shipyard founded in 1904 and has one dock and three slips. MEST can provide rebuilding and repair of vessels up to 120 metres. The shipyard has up to 200 employees.

Torshavnar Shipasmedjan PF was founded in 1962 and has a working berth of $2 \mathrm{x}$ 80 metres and two slipways. The shipyard employs 120-160 workers. 


\subsubsection{Norway}

Norway has traditionally had a large number of yards building different kinds of ships, although during recent decades the number has decreased. Repair and maintenance of ships takes place, according to Norwegian Industry Maritime Branch, at 70 yards and approximately 40 shipyards have shipbuilding activities. Many of the old large shipyards have been converted to offshore-yards. Shipbuilding and maintenance and repair have concentrated on the counties Møre and Romsdal and Nordland.

Maritime Branch (Norwegian Industry) has categorised the number of repair shipyards according to the annual surface area treated. Four shipyards have surface treating activities between $30-40,000 \mathrm{~m}^{2} / y e a r$ and all four shipyards are treating a total annual surface area of $140,000 \mathrm{~m}^{2}$.

Table 2: Norwegian repair shipyards

\begin{tabular}{lccccccc} 
1000 $\mathrm{m}^{2} /$ year & $\mathbf{4 0 - 5 0}$ & $\mathbf{3 0 - 4 0}$ & $\mathbf{2 0 - 3 0}$ & $\mathbf{1 0 - 2 0}$ & $\mathbf{5 - 1 0}$ & $\mathbf{0 - 5}$ & Total \\
Average, $\mathrm{m}^{2} / \mathrm{y}$ & 45 & 35 & 25 & 15 & 7.5 & 3.5 & \\
Number of yards & 1 & 4 & 5 & 10 & 20 & 32 & 72 \\
Area 1000 $\mathrm{m}^{2}$ & 45 & 140 & 125 & 150 & 150 & 112 & 722 \\
\hline
\end{tabular}

The number of dry and floating docks in Norway is 15 and 17, respectively.

\subsubsection{Iceland}

Iceland has a few shipyards for repair and maintenance in the scope of the study. The biggest shipyards are Slippurinn in Akureyri and Stálsmiðjan-Framtak in Reykjavík.

In addition, there are companies, such as Navas, designing ships that are then manufactured outside Iceland.

\subsubsection{Sweden}

Sweden also has traditionally a large number of yards building different kinds of ships, although the number has decreased. There are a few shipyards engaged in shipbuilding and about 20 repair yeards of different sizes along the coast of Sweden. The Swedish Shipyards Association's member companies directly employ approximately 1,200 people. Oresund Dryck Dock is one of the largest repair shipyards in the Nordic countries. Other major shipyards are the Stockholm repair yard and Falk Varv in Falkenberg. 


\subsection{Commonly used techniques at shipyards}

\subsubsection{General introduction and definitions}

Size of the shipyards

The size of ships is one important factor that determines which techniques are technically and economically possible. There is no agreed definition of sizes of shipyards or sizes of ships they can handle. In practice, the size of ship can be described by the length of the ship, the tonnage (gross and net) or the area of the ship to be surface treated.

Most often the number of employees (work hours) and turnover of the shipyard determine the size, like the EU definitions of small and medium size enterprises.

There is, unfortunately, no simple definition of the classification of ship for the purpose of this report.

The number of employees varies a lot and many shipyards have a permanent workforce supplemented by sub-contractors to do painting, grinding and other work. The number of permanently employed workers at the larger Nordic shipyards varies typically between 50 and 200.

The length of ships managed by the Nordic shipyards varies from just a few metres up to $200 \mathrm{~m}$. The capacity of the shipyards (length of the docks and berths) is sometimes used to classify the sizes of the shipyards.

In practice, many of the medium-size Nordic shipyards have dry docks up to 220 $\mathrm{m}$ (in some cases even up to $300 \mathrm{~m}$ ) and floating docks up to $200 \mathrm{~m}$. Berths for outfitting etc. can be up to $400 \mathrm{~m}$ long.

\section{Different weather conditions}

Most shipyard activities take place outdoors. Therefore, an important issue to be considered is different climate and weather conditions. Shipyards locate in coastal areas where humidity is often high and wind may be particularly strong. Denmark's coldest month is February, in which the mean temperature is $0^{\circ} \mathrm{C}$, whereas in January in Finland the temperature averages $-6^{\circ} \mathrm{C}$. On the other hand, in Iceland on almost every day in winter there is a $60 \%$ chance of rain or snowfall.

The traditional outdoor facilities are slipways, dry docks and floating docks. The indoor activities take place in workshops, larger painting halls and, in some cases, also docks with a permanent roof.

An increasing number of small and medium-size shipyards have enclosed docks with roofs and walls. In Norway these are called "Skipsgarasje" ("Ship garage"). The 
arrangement reduces air and noise emissions and prevents rainwater from getting into the dock, which enables work in all weather conditions.

\subsubsection{Life cycle of ships}

Shipbuilding

Today, ships are mostly constructed from shipbuilding steel. Yachts are constructed mostly from shipbuilding steel, aluminium and fibre reinforced plastics (FRP).

The shipbuilding industry includes not only the actual shipyards. A large part of subassemblies and equipment are manufactured elsewhere in metal workshops and transported to the shipyard to be assembled and installed. The whole shipbuilding cluster also includes designing, consulting, system and component and material suppliers. Designing is an important activity since the energy and performance of a ship during operation is very dependent on the design. However, this study focuses on the activities that take place in the shipyards. There are significant differences between the different shipyards and their operations. For example, the extent of external supply of subassemblies varies. Nevertheless, the following steps usually take place at shipyards (also presented in Figure 1).

The shipbuilding starts with fabrication of steel plates into various units and subassemblies by cutting, shaping, bending and welding. Also utilities are assembled and integrated into the units. Joining of assemblies into larger blocks, surface treatment and painting then take place. The completed units are then moved to the graving dock or slipway, where they are joined together to form the vessel. Usually the initial fabrication stages take place indoors in large halls and later joining of subassemblies and units either indoors or outdoors.

Once the hull is structurally complete and watertight, the vessel is launched and the final outfitting can take place. The outfitting includes e.g. the fitting of cabling and piping, the furnishing of galleys and accommodation quarters and installation of propulsion and ancillary machinery. After testing, the ship is delivered. 
Figure 1: Shipbuilding in photographs (pictures taken at Arctech Helsinki Shipyard Oy and Meyer Turku Oy during visit)

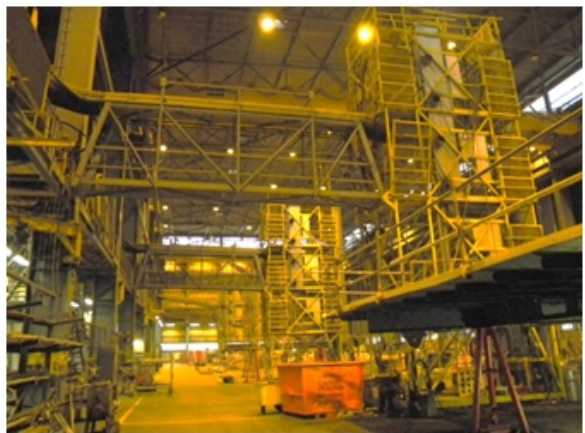

Fabrication of units inside hall

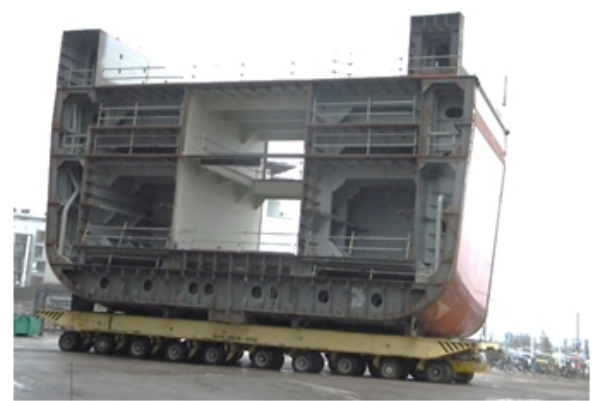

Ready unit

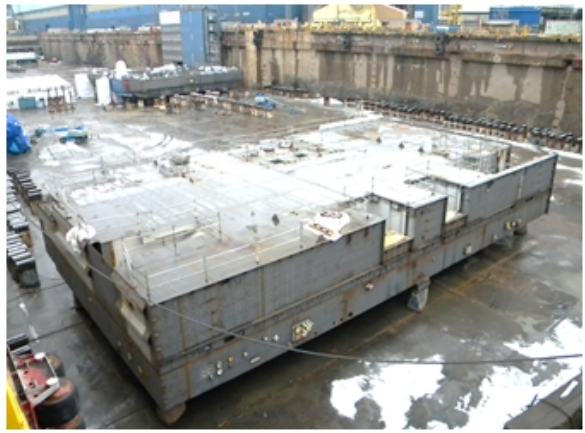

Joining of units at outdoor dry dock

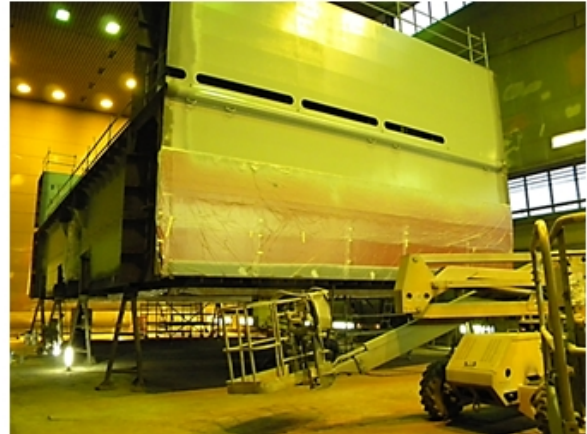

Painting inside hall

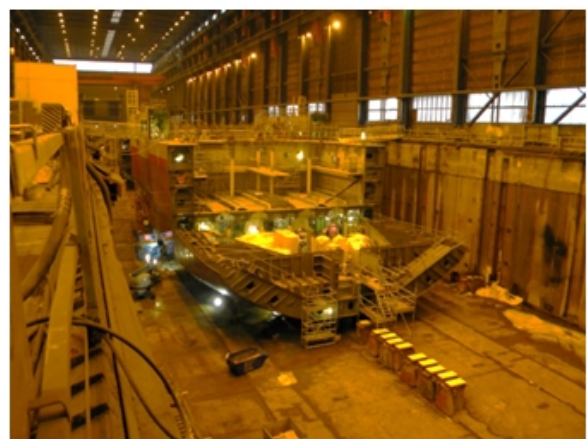

Joining of units at indoor dry dock

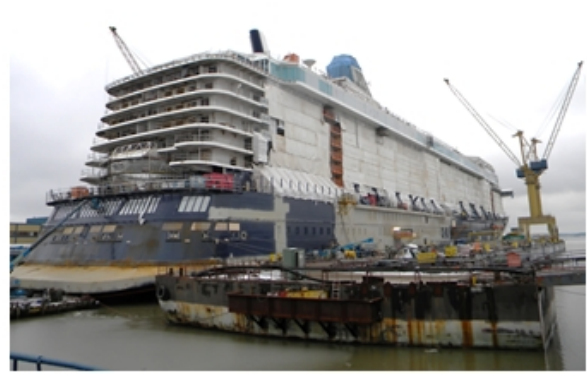

Outfitting

Ship maintenance and repair

The typical maintenance frequency of ships is 3 to 5 years. A ship is taken to a repair dock where it is washed, old paint, rust and marine vegetation is removed and antifouling agents and paints are renewed. 
In particular, marine vegetation is an important issue from a ship economy point of view. Marine vegetation increases friction and fuel consumption, up to $40 \%$ as based on the information available. Removal of marine vegetation can be the sole reason for docking a ship. Efficient prevention of marine vegetation by using the right antifouling for the specific route reduces docking frequency and fuel costs and consumption and the environmental impacts related to the energy consumption.

Rebuilding, repair and maintenance of ships comprise mostly similar operations to shipbuilding, such as metal works, surface preparation and painting, but the potential environmental impacts are potentially more significant and diverse.

Maintenance and repair often takes place at dry docks or floating docks. Slipways and larger painting halls may be used for smaller ships. The activities mainly take place outdoors, but dry dock facilities with a permanent roof also exist.

Old ships potentially contain hazardous substances that pose a risk of dispersing into the environment during maintenance and repair. Emptying tanks and equipment of oil and other chemicals is also a potential risk.

Figure 2: Open dry dock and floating dock for maintenance and repair (picture from Turku Repair Yard Ltd)

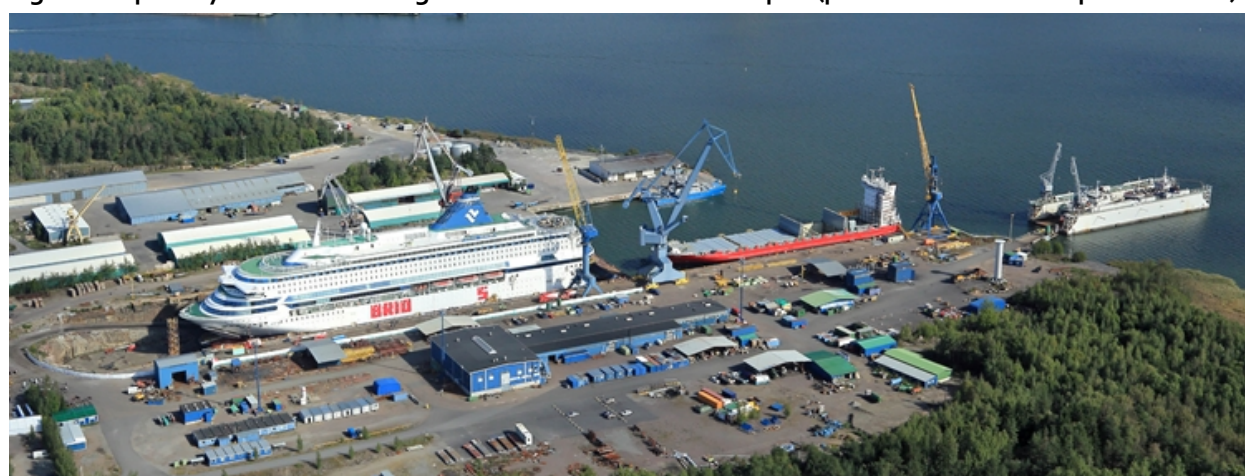

Ship demolition

Demolition of ships includes unit operations such as cutting of steel into smaller parts and sorting materials into different fractions.

Building materials and insulation can contain hazardous substances, such as asbestos, that require special precaution.

At the moment, demolition has only limited significance in the Nordic countries, although due to the tightening of legislation it is possible that in the future more ships will be demolished also in the Nordic countries. Also in repair work and rebuilding partial demolition may take place. 
Cradle to $\mathrm{Cradle}^{\circledR}$ passport for recycling of materials

As an example, Maersk Line has introduced a concept for shipbuilding and recycling of materials to build new ships. The concept was introduced in 2014 when Maersk Line ordered a new series of giant Triple-E ships from the Korean Shipyard DSME.

The concept is named Cradle to Cradle ${ }^{\circledR}$ passport, where a comprehensive datasystem will store data for all materials from approximately 75 suppliers used to build the new ships, like high and low grade steel, copper wiring, hazardous materials etc. The concept Cradle to $\mathrm{Cradle}^{\circledR}$ is a registered trademark of McDonough Braungart Design Chemistry, LLC.

Based on a detailed sorting system, nearly all materials are planned and expected to be recycled without producing a large amount of scrap waste and maintaining the materials in a closed loop.

At the moment it is not known if experiences from the project will be shared with others outside the Sustainable Shipbuilding Initiative (a network of larger stakeholders in the sector) or the experiences will be kept confidential and used as a commercial opportunity.

\subsubsection{Activities at the shipyards}

Shipyard activities both in new shipbuilding and maintenance and repair can be generally divided into metal working, surface treatment and outfitting activities. 
Figure 3: Shipyard activities

Metal working activities

- Cutting (thermal)

- Welding

- Grinding

\section{Surface treatment activities}

- Water blasting

- Abrasive blasting

- Coating

- Painting

\section{Outfitting}

- $\quad$ Piping

- Ventilation

- Electrical equipment

Metal working activities

Metal working activities include thermal cutting, welding and grinding, which are potential sources of air emissions (dust, particles and welding gases) and noise. Also different kinds of waste are produced: recyclable metals, waste oils, paints, as well as dust. In particular, in shipbuilding the amount of scrap metal is significant.

Some metal working activities take place indoors and others outdoors. 
Figure 4: Example of grinding of a ship surface outdoors in winter (picture from Stálsmiðjan-Framtak in Reykjavik)

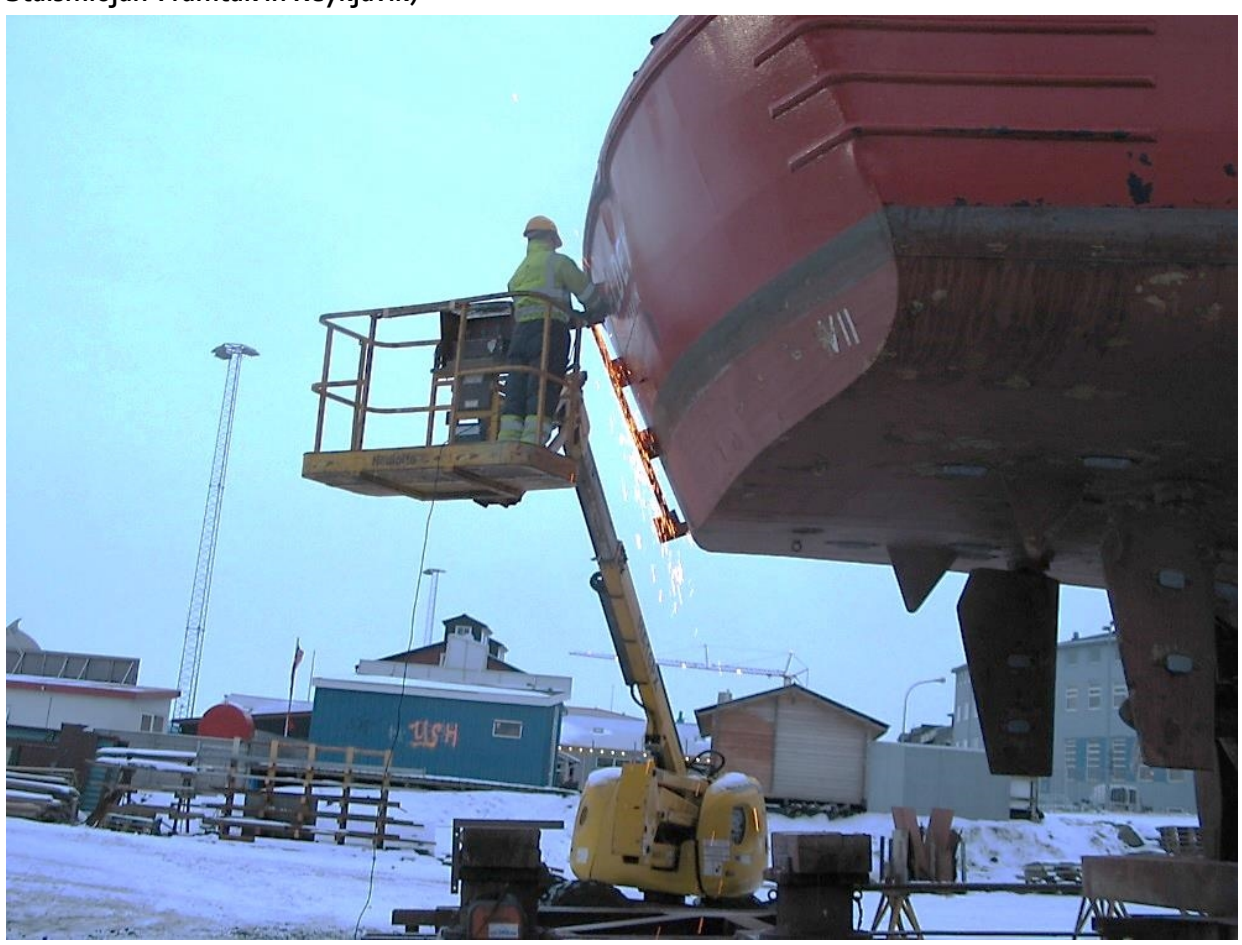


Figure 5: Enclosed hall for repair and maintenance of small ships (picture from Päijänteen Telakka Oy, internet pages of $\mathrm{m} / \mathrm{s}$ Tähti)

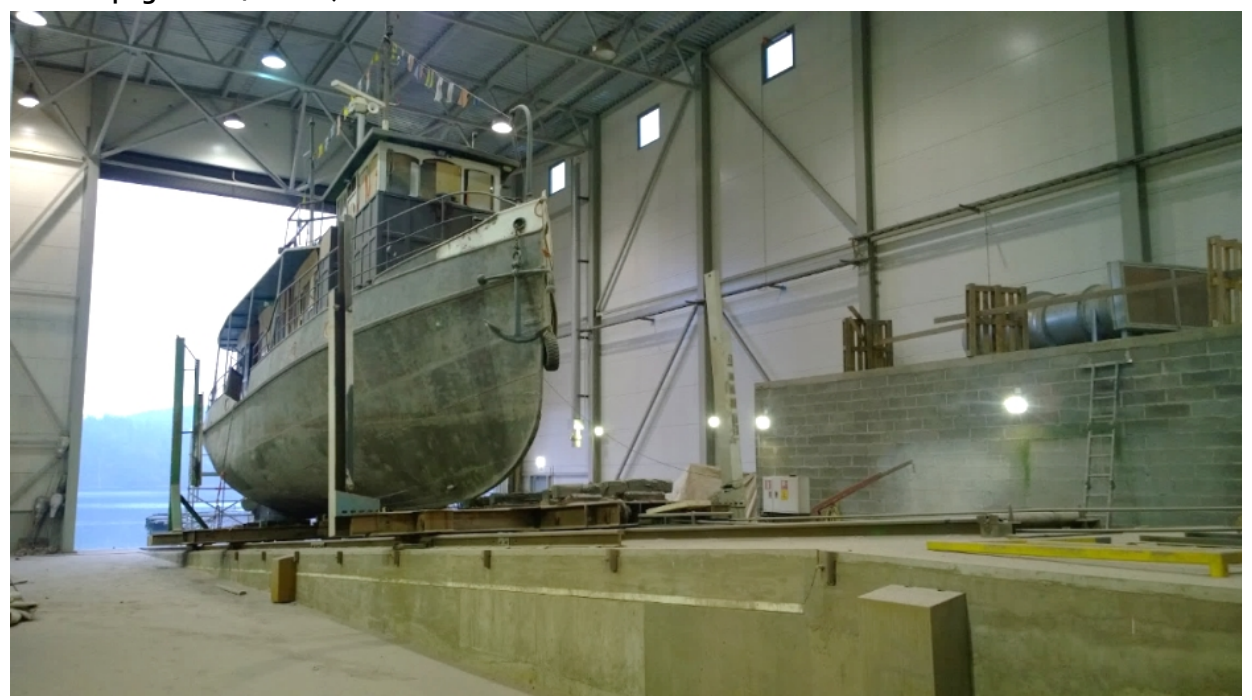

\section{Surface treatment activities}

Surface treatment takes place because of corrosion protection, fouling prevention and appearance of the ship. Corrosion protection is important from a structural and life cycle point of view. Fouling prevention (bacteria, algae and animals such as mussels) by antifouling agents is also important, in particular from an energy consumption point of view. Fouling prevention can increase a ship's energy consumption by up to $40 \%$.

Before painting, the surface needs to be washed and rust and old paint need to be removed. Different techniques are used both outdoors and indoors, such as high pressure or ultra high pressure blasting (UHP), other wet blasting methods or dry blasting. Also different abrasives are used: sand, nickel slag etc. Traditionally, silica sand was used, but not anymore because of the health hazards associated with silica dust. Fine particles of crystalline silica may cause a risk of developing silicosis in lungs. Steel grids are typically used as abrasives in shipbuilding when the activities take place indoors and grids are recycled.

Blasting produces noise, wastewater, waste and dust. In dry blasting, large amounts of abrasive waste are produced containing heavy metals and other hazardous substances. UHP blasting is an option with no other abrasive than water used. 
Figure 6: Traditional dry blasting activity at large outdoor dry dock (picture from Turku Repair Yard Ltd)

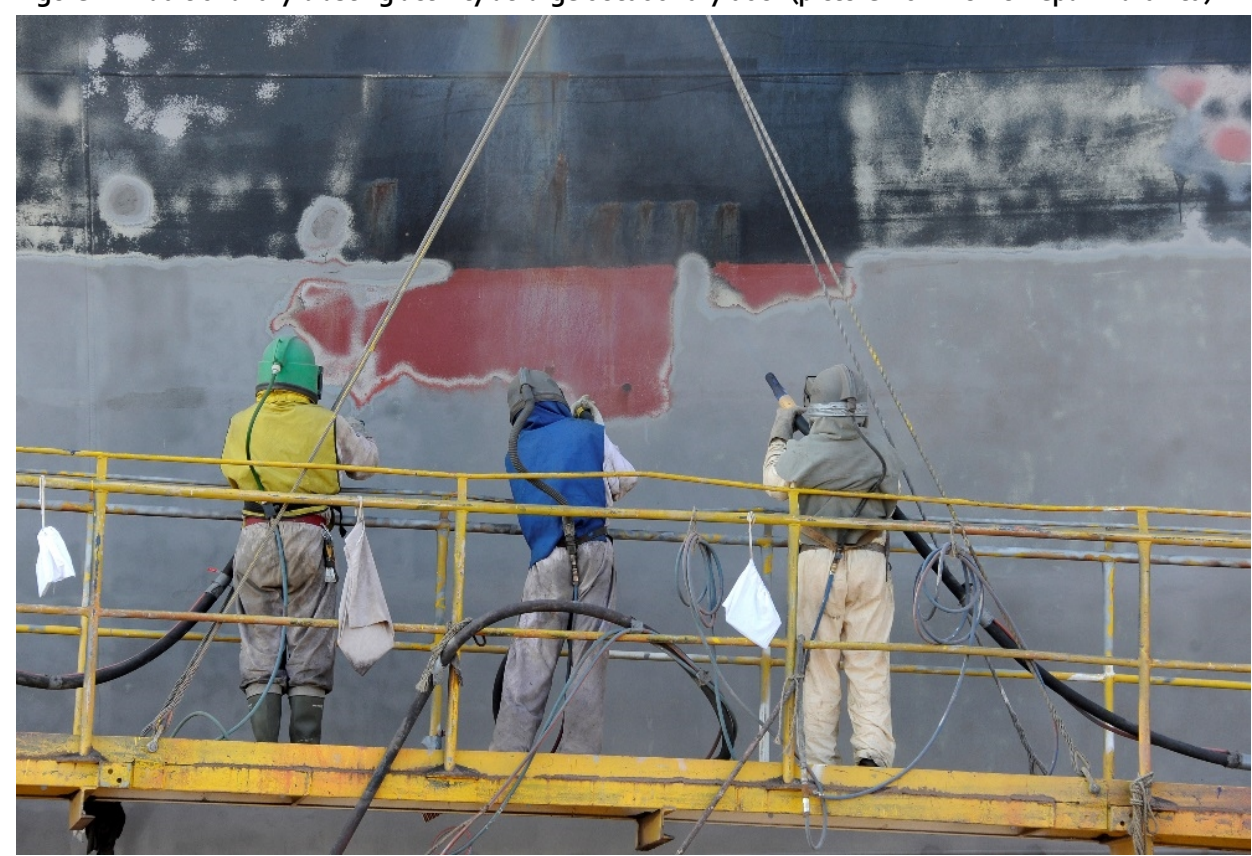

Painting usually takes place by wet spray painting. Rollers and brushes can be used for coating yachts. Painting is a source of emissions of volatile organic compounds (VOC).

VOC emissions may be reduced by the right selection of paint; whereas the limitations of low VOC paints and solvent free paints shall be taken into account, they may also be more expensive. If surface treatment is done with good quality and proper methods and paint, unnecessary docking and surface treatment is avoided and VOC emissions are reduced overall.

Selection of paints and quality assurance often takes place by ship owner or paint manufacturer based on corrosion protection, appearance, antifouling and warranty requirements for the specific purpose. Shipyards select paints only in a few cases. Therefore, also the possibilities to control VOC emissions by shipyards are limited.

\section{Outfitting}

Outfitting takes place at the outfitting quay where also welding, grinding, blasting, and painting takes place. 


\section{Brief regulatory review}

The BREF document on Surface Treatment Using Organic Solvents (STS) is being revised according to the IED. The current BREF is from 2007 and its review has already started.

Annex I of the IED includes: "Surface treatment using organic solvents, in particular for coating, degreasing, waterproofing, sizing, painting, cleaning with an organic solvent consumption capacity of more than $150 \mathrm{~kg}$ per hour or more than 200 tonnes per year".

Other relevant EU legislation that regulates shipyards includes:

- Water Framework Directive 2006/60/EC.

- Waste Framework Directive 2008/98/EC.

- Regulation on the prohibition of organotin compounds on ships 2008/536/EC.

In the EU, the trade and use of antifouling agents require authorisation under the Biocidal Regulation 528/2012 (previously Biocidal Directive 98/8/EC). Authorisation requires an acceptance procedure where risks to human health and the environment are assessed. In principle, compounds containing carcinogens (classes $1 A$ and1 $B$ ), mutagens (categories $1 A$ and $1 B$ ), toxic to reproduction (categories $1 A$ and $1 B$ ), having endocrine-disrupting properties or being persistent, bioaccumulative and toxic or very persistent and very bioaccumulative do not get authorisation. The European Chemical Agency coordinates the registration of biocidal products and provides an EU-wide authorisation. Also national authorisation may be required. In this case, the application is assessed and the authorisation granted by a competent national authority.

The International Maritime Organization (IMO) adopted a new International Convention for the Safe and Environmentally Sound Recycling of Ships in Hong Kong, China in May 2009. The IMO Convention imposes new requirements on ships from "cradle to grave". It obligates shipowners to sell their redundant ships only to recycling facilities that meet IMO standards and which have been approved by the Flag State and by the authorities in the Ship Recycling State. The Convention is being transitioned into EU and national legislation. 


\section{$2.1 \quad$ Finland}

The IED is implemented in Finland as part of the renewed Environmental Protection Act (527/2014) and Decree (713/2014). According to the Decree (713/2014), the Regional State Administrative Agencies (AVI) in Finland licence shipyards. Also surface treatment using organic solvents with an organic solvent consumption capacity of more than 10 tonnes per year triggers a need for an environmental permit.

The Centres for Economic Development, Transport and the Environment (ELY Centres) supervise adherence to the environmental and water permits granted by AVI. Principally shipyards of all sizes require an environmental permit, whereas ELY Centres based on a case-specific assessment of risk of environmental pollution determine whether a specific operation requires an environmental permit or not.

In the legislation there are no specific requirements for shipyards.

\section{2 Åland Islands}

Åland has its own provincial laws in a number of important areas based on its autonomous position. The environmental licensing for industrial plants is outlined in the Provincial law on environmental protection (ÅFS 2008:124, ändrad ÅFS 2015:14) and decree ( $\mathrm{FFS} 2008: 130$, ändrad ÅFS 2015:15), where it is specified that environmental review is required for shipyards intended for boats which are longer than 12 metres or if organic solvent consumption in painting is more than 10 tonnes per year. Largerscale shipyards and organic solvent use would need an environmental permit. The permitting authority is the environmental and health protection agency of Åland (ÅMHM).

\subsection{Denmark}

Outdoor surface treatment activities on shipyards are covered by Executive Order ("Bekendtgørelse om overfladebehandling af skibe", BEK no. 1188 from December 2011) and after the Executive Order on VOC (BEK no. 1491 from 07/12/2015) including demand to apply a programme for reduction of the emissions from the use of VOC containing products. The order on VOC is a close transcription of the IED. Conditions based on the two executive orders mentioned above are included in the environmental permit. 
However, shipyards might be exempted from the emission limit values in the VOC Order if technical or economic reasons do not make it feasible or if the shipyard can document that BAT is used.

All surface treatment activities at sea and outside the shipyards or dock areas are not allowed according to Executive Order no. 1188. Surface treatment of ships inside a dock, on a slipway or within the area of the shipyards must be managed with effective mitigation measures, including use of necessary encapsulation to avoid significant emission of pollution. Before ships leave a dock or slipway, all materials that can pollute the sea, including abrasives, removed paints, oil etc., must, according to the Executive Order no. 1188, be removed.

A new Executive Order for environmental permitting of companies (BEK no. 514 from 27/05/2016) was made effective recently and is a part of the new environmental regulation system based on a digitalisation regime.

Shipyards are subject to environmental permitting under the A204 activity (Steel shipyards and floating docks) mentioned in the BEK. No. 514 from 27/05/2016. Larger shipyards will fall under the IED rules. The competent environmental authority is the municipality.

New shipyards or shipyards planning to enlarge production will need to obtain an environmental permit from the environmental authority prior to starting production.

If a shipyard additionally has larger areas with machine shop activities, the specific activities are covered by general binding rules and not by the environmental permit.

The discharge of wastewater and stormwater is subject to a discharge permit, which is issued for both discharge to the public sewer system and for direct discharge into the sea. Discharges include some pre-treatment activities such as use of a sand filter and an oil separator. Clean stormwater or roof water can be discharged to the sea with minimal pre-treatment.

The shipyard will have to monitor compliance by sampling and measurements as prescribed in the discharge permit. If emission limits values are not met, the wastewater/stormwater must be pre-treated further.

Shipyards that have machine workshops and indoor surface treatment activities with a production area larger than $1,000 \mathrm{~m}^{2}$ are regulated by a new Sector Executive Order (BEK no. 1434 from 21/12/2015). The Executive order covers machine workshops handling items of iron, steel and other metals and having abrasive, welding, cutting, blasting and painting processes.

Machine workshops no longer need an environmental approval for their operation, but will need to comply with these general binding rules instead. General rules are set for emissions to air from a range of processes, including emission limit values and rules on minimum stack heights. New shipyards or shipyards planning to enlarge 
production of the machine shop area will need to notify the environmental authority, while showing that the production complies with the general binding requirements established in the Sector Executive Order. Companies can start operation if the environmental authorities have not put forward any objections within a period of 4 weeks from notification. Objections would result in additional conditions for the operation.

The environmental authority will, within a period of 3 months, conduct a start-up inspection for new shipyards to assess if the company is in compliance based on the notification submitted by the company.

Machine workshops can apply for a derogation or exemption from the general binding rules.

Examples of emission limits values for machine workshop activities can be seen in Table 3.

\section{Table 3: Danish emission limit values for machine workshop activities}

Processes with cooling and lubricant agents

Oil aerosols, vegetable origin

Oil aerosols, mineral origin

Exhaust air filtration efficiency (*)

Grinding processes (dust)

Powder painting (dust)

Wet painting

Zinc dust

Epoxy dust

Total dust

Organic paint thinner (VOC)

Particle filter efficiency from paint box

$$
\begin{aligned}
& 5 \mathrm{mg} / \mathrm{Nm}^{3} \\
& 1 \mathrm{mg} / \mathrm{Nm}^{3} \\
& 99 \% \\
& 5 \mathrm{mg} / \mathrm{Nm}^{3} \\
& 5 \mathrm{mg} / \mathrm{Nm}^{3} \\
& 5 \mathrm{mg} / \mathrm{Nm}^{3} \\
& 5 \mathrm{mg} / \mathrm{Nm}^{3} \\
& 10 \mathrm{mg} / \mathrm{Nm}^{3} \\
& 300 \mathrm{mg} / \mathrm{Nm}^{3} \\
& 90 \%
\end{aligned}
$$

Note: * * If exhaust air filtration efficiency is in compliance, machine workshops do not need to document the other parameters.

\section{$2.4 \quad$ Norway}

The IED is implemented in Norwegian legislation by the Pollution Act. Surface treatment using organic solvents with an organic solvent consumption capacity of more than $150 \mathrm{~kg}$ per hour or more than 200 tonnes per year triggers a need for an environmental permit. The permitting authority is the Norwegian Environment Agency (Miljø-direktoratet).

Emissions from shipyards not covered by IED are regulated by "forurensningsforskriften" chapter 29. The regulation has emission standards for emissions and noise for mechanical surface treatment and maintenance activities of metalcon- 
struction, like shipyards. The County Governor is the environmental authority according to chapter 29.

Emission of prioritised substances must be limited to the extent possible and only be discharged if it has no significant effect on the environment. Similar regulation is in place for emission of VOCs ("for-urensningsforskriften" chapter 9).

However, the regulation accepts an exemption if enclosed conditions are not possible to establish, e.g. at shipyards. A consequence is that emissions standards for fugitive emissions are not applied ("for-urensningsforskriften" chapter 9).

Miljødirektoratet (Norway) has in its guideline "Regulation of pollution from shipyards (Veileder M-487, 2016)" given guiding emission limit values for wastewater. The guiding emission limit values for some prioritised substances are divided into two groups according to the activity level of the shipyards, the age of installation and year of establishment, and treatment of older ships with a potential content of TBT. Removed paint with TBT must be handled and disposed of according to the regulation.

The group 1 covers shipyards which have annual surface treatment activities exceeding 10,000 $\mathrm{m}^{2}$ and which are established after the new rule came into effect. The guiding emission limit values are given as $\mathrm{mg} / \mathrm{m}^{2}$ wet surface area treated and as a concentration in $\mathrm{mg} / \mathrm{l}$ blasting water based on use of $12 \mathrm{I}$ water $/ \mathrm{m}^{2}$ wet treated area. Oil is given only as a concentration in blasting water.

Table 4: Guiding wastewater emission limit values for group 1 shipyards in Norway

Substance $\mathrm{mg} / \mathrm{m}^{2}$ wet surface $\mathrm{mg} / \mathrm{l} \mathrm{blasting} \mathrm{water}$

$\begin{array}{lcc}\mathrm{As}, \mathrm{Pb}, \mathrm{Cr} & 2.4 & 0.2 \\ \mathrm{Cd}, \mathrm{TBT} & 0.24 & 0.02 \\ \mathrm{Cu} & 36 & 3 \\ \mathrm{Hg} & 0.06 & 0.005 \\ \mathrm{Oil} & & 50\end{array}$

The emission limit values for group 1 means in practice according to the guideline that the wastewater must be collected and treated.

Group 2 covers shipyards treating less than $10,000 \mathrm{~m}^{2}$ surface and which are established before the new rule came into effect. The guiding emission limit values are given as annual total maximum emissions. 
Table 5: Guiding wastewater emission limit values for group 2 shipyards in Norway

\begin{tabular}{lcc} 
Substance & Annual total emission, $\mathbf{g}$ & Concentration, $\mathrm{mg} / \mathrm{l}$ \\
$\mathrm{As}, \mathrm{Pb}, \mathrm{Cr}$ & 50 & - \\
$\mathrm{Cd}$ & 10 & - \\
$\mathrm{Cu}$ & 2,000 & - \\
$\mathrm{Hg}$ & 5 & - \\
$\mathrm{Oil}$ & - & 50 \\
\hline
\end{tabular}

Shipyards belonging to group 2 are allowed to discharge blasting water without wastewater treatment if the shipyards can document that they able to collect $80-90 \%$ of removed paint and that they are not exceeding the guiding emission limit values for the prioritised substances.

\subsection{Sweden}

In Sweden, the environmental licensing for industrial plants is outlined in the Swedish Environmental Code and is based on case-by-case assessments of environmentally hazardous activities and taking into account the local conditions: licensing of large and medium-size installations takes place by courts or county administrative boards, which also oversee larger industrial installations.

The municipal health and environmental committee supervises smaller industrial installations including smaller shipyards.

\subsection{Iceland}

The environmental regulations for industry licensing are based on the directive $96 / 61 / E C$, although the IED has not yet been implemented in Iceland. All the shipyards in Iceland use less than $150 \mathrm{~kg}$ of organic solvents per hour and 200 tonnes/year so they are not included in the IED directive. The environmental permits for smaller shipyards are regulated and inspected by the local health authorities. 


\subsection{Faroe Islands}

The Faroe Islands have their own laws in a number of important areas based on their autonomous position. The environmental legislation for industrial plants is outlined in the Act on environmental protection from 1988. Shipyards are listed in the Annex of the act as an industry, which has to have an environmental approval. The Environmental Agency of Faroe Islands gives the approval. 



\section{Environmental impacts from shipyards and key environmental indicators (KEI)}

Environmental impacts from shipyards in the Nordic countries are different for a number of reasons, which, among others, are:

- Impacts from shipbuilding differ a lot from repair and maintenance.

- Different facilities like dry docks, floating docks and slipways of different sizes have different possibilities to prevent emissions; some shipyards are older and not equipped with technical arrangements to handle emissions (like barriers and wastewater treatment facilities), which can be difficult to be installed afterwards.

- Different sizes of ships.

- Different climatic conditions (temperature, tide, snowfall etc.).

- Site settings (some shipyards are located in cities or towns close to residential areas or close to nature protected areas).

The KEl in the scope of this study are (in non-prioritised order):

- Air emissions (dust and VOC).

- Noise emission.

- Wastewater emissions and stormwater (hazardous substances such as heavy metals and oils).

- Waste (steel in shipbuilding, blasting material with hazardous substances in repair and maintenance).

- Chemicals (paints and antifouling agents).

- Contamination of soil, groundwater and sea and lake water and sediment.

- Energy efficiency and design for environment (shipbuilding).

In the next chapter, BAT are described within each of the listed KEls. 


\subsection{Air emissions}

\subsubsection{Particulates and dust}

Particulate and dust emissions from blasting and painting depend on technology used, applicability and economic feasibility, which all vary.

Wet blasting, such as UHP blasting, produces far less dust compared to dry blasting. In outdoor activities, the risk for particulate emissions are greatest in open operations exposed to wind. Particles from blasting and overspray can in the worst case spread several kilometres. Location and shape of dock also affect wind conditions. Partially closing with curtains, nets or tenting is used to mitigate particulate emissions, but also increases costs. Partial closing does not eliminate all particulate emissions. Closed hall is another possibility to reduce dust from dry blasting, mainly in use in new shipbuilding, but increasingly also at small and medium-size repair yards. Indoors, dust and fumes can be an occupational health and safety risk, if not collected.

Air emissions from traffic are not discussed in more detail. Nevertheless, it is noteworthy that if material transportation in and out of shipyards can be optimised, for example by batch deliveries, it saves both money and the environment.

\subsubsection{Volatile organic compounds (VOCs)}

Painting is a source of fugitive emissions of VOCs. In addition to painting, VOCs are emitted in cleaning of painting tools, engine parts etc.

Traditional paints have typical VOC content of 50\%. Today, paints that have lower a VOC content of typically $30 \%$ or less ("Low-VOC paints") are widely applied in the Nordic countries. Also solvent-free paints are used, although applications are still limited and prices higher. Generally waterborne paints can be used only in limited applications like interior areas and prefabricated parts of ships in shipbuilding and they are rarely used in repair shipyards.

The applicability of paints depends on various affecting factors. Issues like route of the ship affect selection of paints and antifouling. For example, some paints are suitable for ice conditions, some are not. Selection of paints and quality assurance takes place by the shipyard, ship owner or paint manufacturer based on corrosion protection, appearance, antifouling and warranty requirements for a specific purpose. Many paints and antifouling are not applicable in Nordic countries, nor working in ice conditions, for example silicone paints. Some repair yards do not use antifouling at all.

Weather conditions during painting must also be taken into consideration. Paints require different minimum temperatures and hardening times in different tempera- 
tures. Generally, solvent-free paints and waterborne paints require a higher painting environment $\left(+10^{\circ} \mathrm{C}\right.$ or more) as compared to low VOC paints and traditional paints (-10 ${ }^{\circ} \mathrm{C}$ or more). In an enclosed environment, temperature may be increased by heating, which, on the other hand, results in additional costs and air emissions from heating. There are also differences in how much humidity the paint stands.

Economy is an important factor, although it is not just the price of the paint per litre. Different paints need a different number of layers and layer thicknesses, which directly determines the consumption of the paint. Also the quality and condition of the previous paint job is a significant factor in paint consumption. Also life cycle aspect is important; how many years the paint can stand in use. Some paints mitigate vegetation better, which determines how often docking is needed, also affecting fuel consumption of the ship.

If surface treatment is done with good quality and proper methods and paint, unnecessary docking and surface treatment is avoided and also VOC emissions are reduced overall.

In many environmental permits of shipyards there are specific limits for VOC emissions and/or a shipyard may be obliged to have a $\mathrm{VOC}$ reduction plan. In reduction of VOC emissions there are several challenges:

- Limitations in applicability of paints having low VOC content or no VOC and price.

- Selection of paints and quality assurance often takes place by ship owner or paint manufacturer based on corrosion protection, appearance, antifouling and warranty requirements for specific purposes. The shipyard selects paints only in a few cases. Therefore, also possibilities to control VOC emissions by shipyards are limited. In the worst case, the annual tonnage limit for VOC limits the number of ships that can be repaired and maintained per year.

- Variation in number and type of production per year; with shipbuilding for example, in a ferry there is much more indoor painting as compared to an icebreaker.

\subsection{Noise and light}

Noise is produced in various operations: machinery, grinding, sawing, blasting, compressors, transport, cranes, hoods and fans as well as testing sound alarm equipment. Capsulation is a way to reduce noise from indoor activities, whereas in outdoor activities mitigation of noise is more difficult. In some advanced models of UHP noise is efficiently reduced by vacuum or use of a box around the spear head. 
Emission limits correspond to general industrial requirements. Typically, there are different noise limits for daytime (e.g. $55 \mathrm{~dB}$ 7:00-22:00) and nighttime (e.g. $50 \mathrm{~dB}$ 22:00-7:00). Also, the surrounding land use can affect the noise limits set. Noise limits in the different Nordic countries and different possibilities to mitigate noise were recently discussed in more detail in the publication "Best Available Technique: Buller från bergtäkter" (2013).

Some of the shipyards are very close to residential houses. Also light can cause nuisance where residential houses are nearby.

Also occupational health and safety limits shall be obeyed and personal protection equipment shall be used when needed.

\subsection{Wastewater emissions and stormwater}

The sources of wastewater at shipyards are numerous and include, among others, cleaning of ship hulls, tanks and other surfaces and use of different equipment using water. The pollutants are oil, grease, sludge, remains from grinding and blasting, paint and antifouling agents etc.

The majority of the docks have no possibilities to control the wastewater and stormwater from the docks as they are open and so-called wells are directly connected to the sea. Consequently, releases of hazardous substances to the soil or sea can occur. In modern dry docks and slipways, flushing water may be collected and treated.Spent blasting media, dust and other waste shall be dry collected, but in older shipyards this is not always possible to be done efficiently (in practise dry cleaning can be challenging).

In general, it is a big challenge in the Nordic countries to minimise the discharge of wastewater from docks. The best way to minimise wastewater is to limit the access of stormwater by full or partly enclosed docks. 
Figure 7: Dry dock where blasting media, dust and other wastes can be dry collected (picture from Turku Repair Yard Ltd)

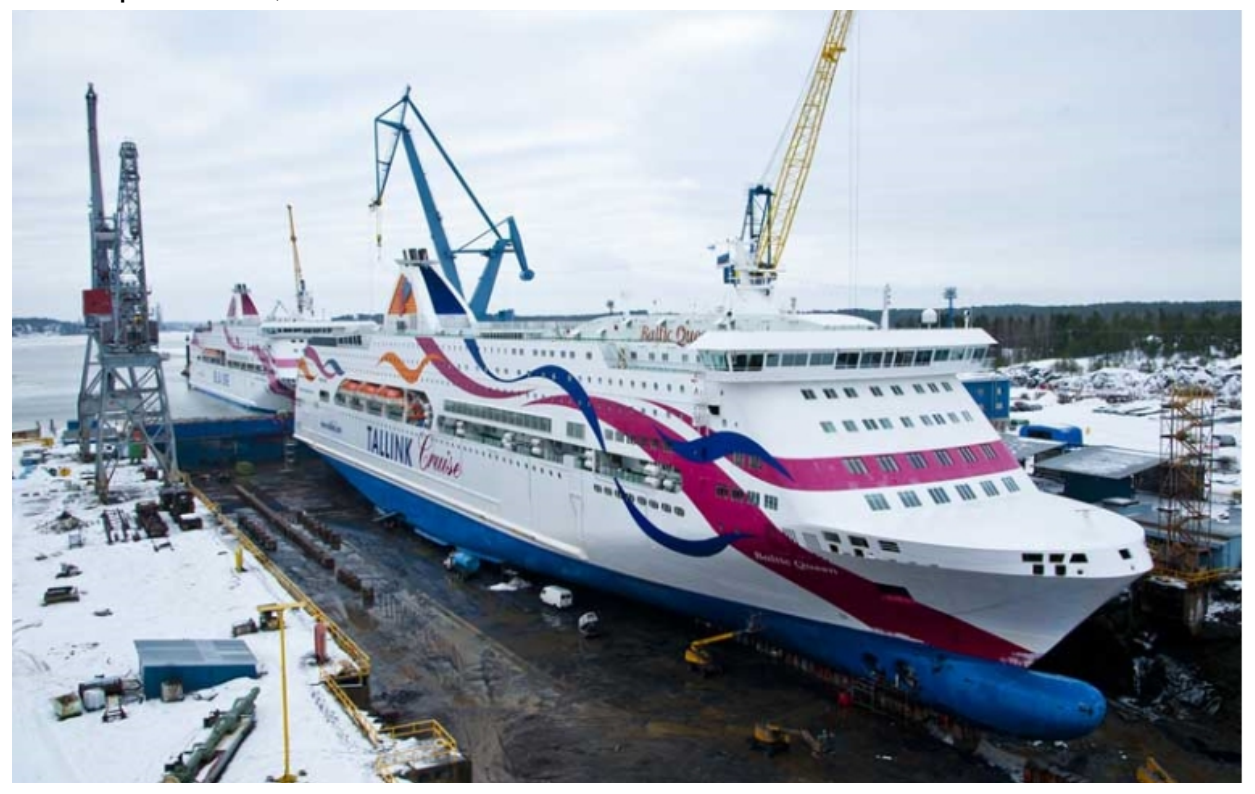

Figure 8: Traditional slipway

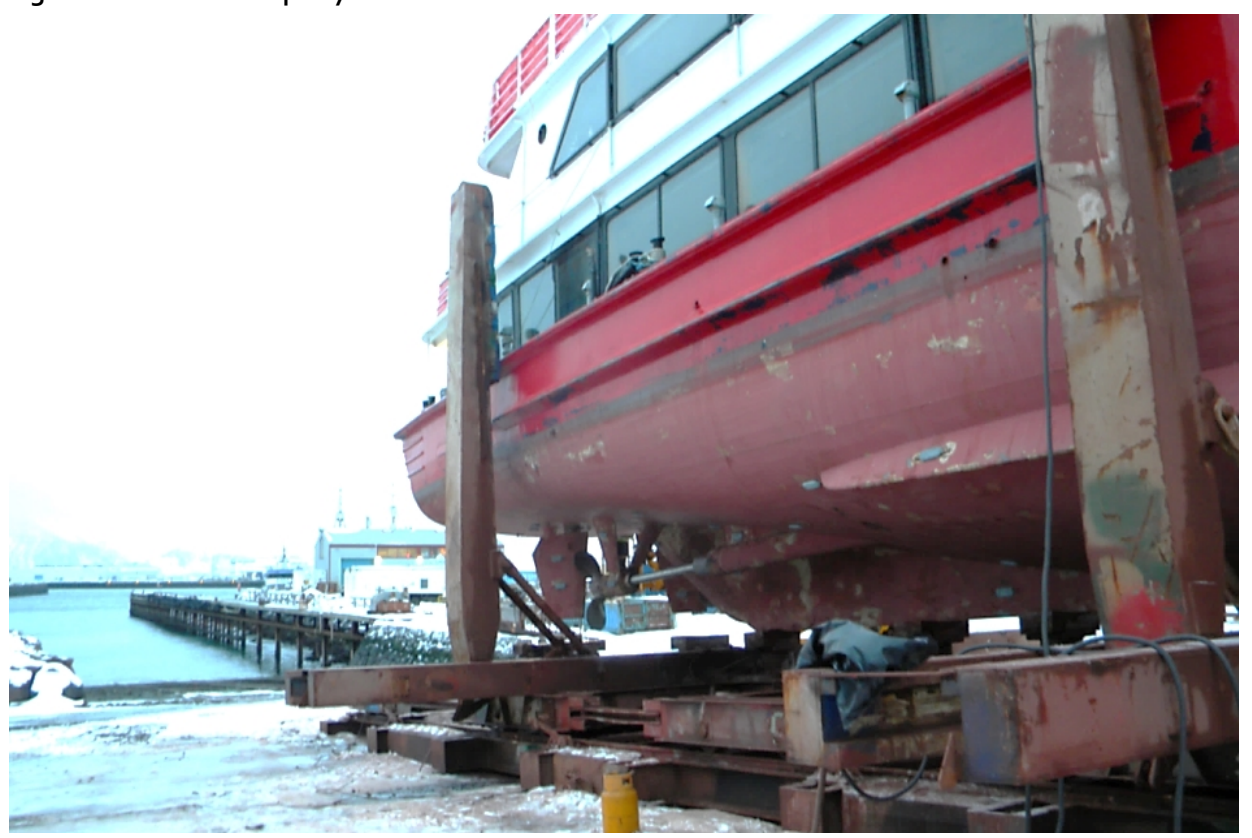




\subsection{Chemicals}

Surface treatment of ship bottoms and sides will release pollutants like paint and biocides, containing hazardous substances like heavy metals, lead and zinc. TBT was used before a ban was introduced in 1990. A small amount of TBT will still be released during surface treatment. Today, the most commonly used biocides are copper compounds, for example $\mathrm{Cu}_{2} \mathrm{O}$ and $\mathrm{CuSCN}$.

Companies and universities work intensively to find more environmentally friendly and at the same time technically durable and economic antifouling for ships. For example, silicone technology has been tested during some years as an alternative to biocidcontaining paints. When stricter regulation on the use of biocid-based paints is in place the silicone technology is expected to be an attractive alternative. Also, for example, copper nanoparticles and biodegradable polymers have been studied and tested. Other scientists look for natural substances as an alternative. Natural compounds under research are, for example, terpenoids, steroids, carotenoids, phenolic furanones, alkaloids, peptides and lactones extracted from marine organisms and showing antifouling activities.

Research and development in paints strives to widen the applicability of low-VOC and VOC-free paints.

In modern shipyards, areas where chemicals are stored and handled are surfaced, but in older shipyards this is not always the case. 
Figure 9: Paint storage at a repair shipyard

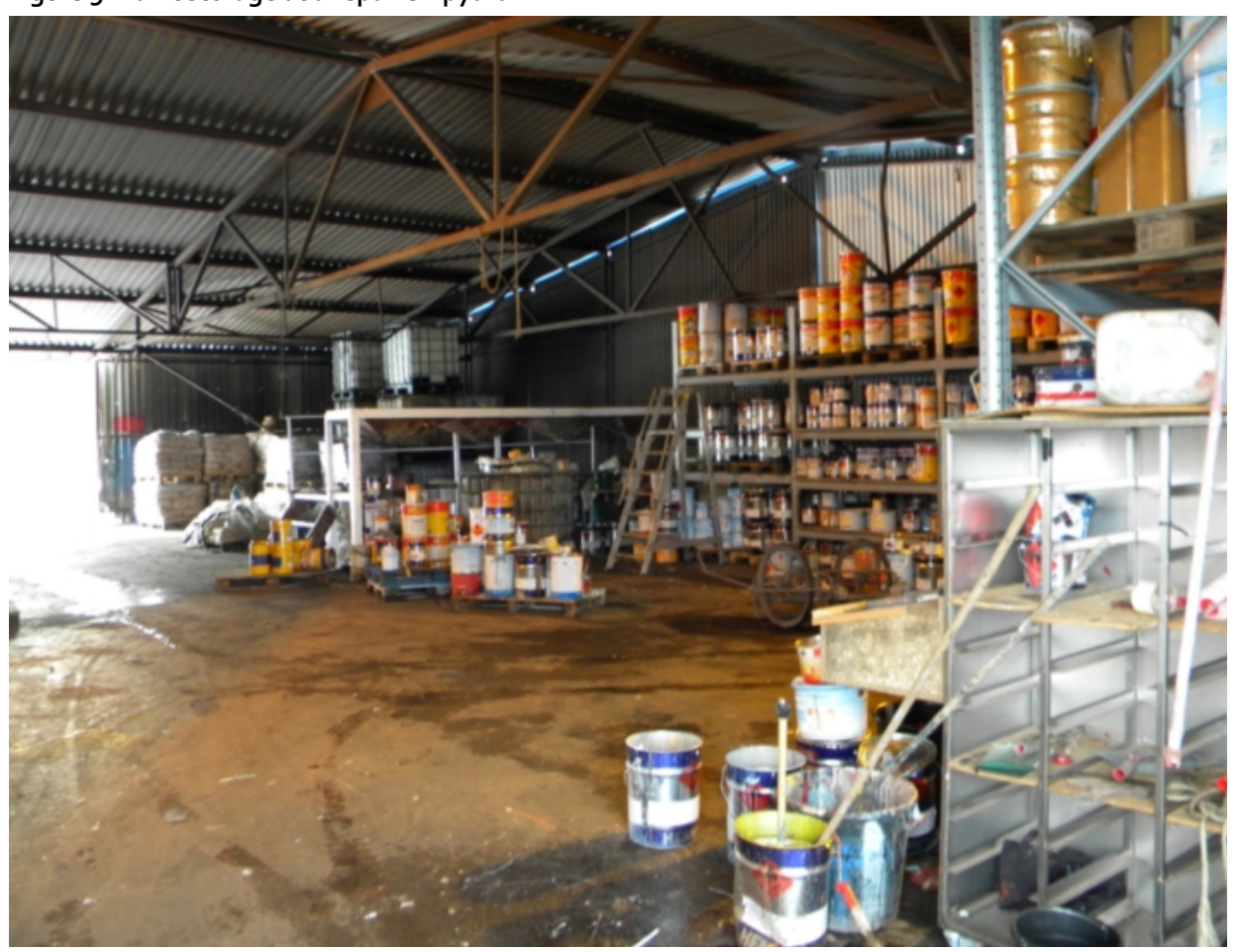

\subsection{Wastes}

Important waste fractions produced at shipyards are scrap metal, used blasting media, oil-containing waste, paint waste and used solvents. The source separation of different waste fractions and the reuse, recycling and recovery of waste should take place.

In shipbuilding, large amounts of metal scrap are produced, whereas blasting usually takes place in enclosed halls where steel grids are used as an abrasive and are recycled several times.

In repair yards, with dry blasting the amount of produced blasting waste is significant. Spent blasting abrasive usually cannot be recycled. Consumption of blasting media can be $20-200 \mathrm{~kg} / \mathrm{m}^{2}$ (typical figure $40-50 \mathrm{~kg} / \mathrm{m}^{2}$ ), whereas the amount of removed paint, rust etc. can be $0.5 \mathrm{~kg} / \mathrm{m}^{2}$. Dry collection of this waste is important to minimise emissions to wastewater, stormwater and sediment. Consequently, waste management costs can be significant, up to several hundreds of euros per 
tonne if the waste needs to be landfilled. Sometimes waste can be delivered for material recovery purposes, reducing the waste management costs. Possibilities to recover the material depend on its properties. The typical composition of a mixture of paint and blasting waste in analysis by Alfons Håkans Oy Ab at Suomenlinna is shown in Table 6.

Table 6: Composition of mixture of paint and blasting waste (reference: Peled 2013)

$\begin{array}{lc}\text { Substances } & \mathrm{mg} / \mathrm{kg} \\ \mathrm{As} & 18 \\ \mathrm{Cd} & 0.5 \\ \mathrm{Cr} & 92 \\ \mathrm{Co} & 34 \\ \mathrm{Cu} & 690 \\ \mathrm{Ni} & 51 \\ \mathrm{~Pb} & 380 \\ \mathrm{An} & <10 \\ \mathrm{~V} & 20 \\ \mathrm{Zn} & 860 \\ \mathrm{Hg} & 0.4 \\ \mathrm{PAH} & 32 \\ \mathrm{PCB} & 0.13 \\ \text { Oil hydrocarbons } & 960 \\ \text { TVOC } & 59\end{array}$

With UHP, blasting waste produced is only the removed paint, rust and small amounts of wastewater. Concentrations of hazardous substances can be higher than in a mixture of paint and blasting waste, but the volume that needs special treatment is only a fraction.

In repair works where old equipment and structures are replaced, special precaution is required because of potential hazardous substances, like asbestos.

\subsection{Contamination of soil, groundwater, sea, lake water and sed- iment}

Historically, shipyards have resulted in soil and sea sediment contamination. In the old days, also various wastes were used in backfilling the sea.

Possible releases of hazardous substances into soil or sea can occur when necessary precautions are not applied and required from the shipyards. All wastewater, dust and other waste shall be collected. Adequate and regularly inspected and maintained 
spill kits and other emergency provisions and procedures minimise damage in case of an emergency situation.

Table 7 shows analysis results of hazardous substances in sediment near former and current shipyards of Suomenlinna, Helsinki. Analysis results may vary a lot depending on various local conditions and whether the area has been dredged. In comparison, near Hietalahti shipyard also in Helsinki much higher normalised TBT concentrations have been analysed, $1200-4300 \mu \mathrm{g} / \mathrm{kg}$.

Table 7: Analysis of hazardous substances in sediment in Helsinki area near former and current shipyards of Suomenlinna (reference: environmental permit of Suomenlinna repair yard)

\begin{tabular}{|c|c|c|c|c|c|c|c|c|c|}
\hline $\begin{array}{l}\text { Normalised concen- } \\
\text { tration } \mathrm{mg} / \mathrm{kg} \text { dry } \\
\text { matterm, TBT } \mu \mathrm{g} / \mathrm{kg} \\
\text { dry matter }\end{array}$ & $\mathrm{Hg}$ & As & Cd & $\mathrm{Cr}$ & $\mathrm{Cu}$ & $\mathrm{Ni}$ & $\mathrm{Pb}$ & $\mathrm{Zn}$ & TBT \\
\hline Point 1 (0-5 cm) & 0.39 & 8 & 0.4 & 43 & 51 & 20 & 82 & 108 & 200 \\
\hline Point $2(0-5 \mathrm{~cm})$ & 0.49 & 8 & 0.5 & 55 & 59 & 22 & 108 & 156 & 150 \\
\hline Point $3(0-5 \mathrm{~cm})$ & 1.49 & 11 & 0.8 & 56 & 133 & 24 & 280 & 228 & 186 \\
\hline Point $1(5-10 \mathrm{~cm})$ & 0.47 & 7 & 0.3 & 41 & 32 & 18 & 73 & 119 & 24 \\
\hline Point $2(5-10 \mathrm{~cm})$ & 0.64 & 8 & 0.5 & 54 & 56 & 22 & 98 & 142 & 140 \\
\hline Point $3(5-10 \mathrm{~cm})$ & 1.82 & 12 & 1.1 & 51 & 118 & 24 & 383 & 258 & 107 \\
\hline Level 2 * & 1 & 70 & 2.5 & 270 & 90 & 60 & 200 & 500 & 150 \\
\hline
\end{tabular}

Note: * Above level 2 dredged sediment shall not be disposed of in the sea in Finland. Below this level disposal is to be assessed on a case-specific basis (Ministry of the Environment of Finland, 2015).

\subsection{Energy efficiency and design for environment}

Energy efficiency and design for environment is important to be taken into consideration in particular in the design and building of new ships.

The fuel cost represents the most significant cost item in shipping. In maintenance and repair, in particular marine vegetation is an important issue from a ship economy point of view. Marine vegetation increases friction and fuel consumption, by up to $40 \%$. Efficient prevention of marine vegetation reduces docking frequency and reduces fuel costs and consumption.

It is noteworthy that certain low solvent paints need minimum temperature conditions. In practice, heating may be needed to achieve such conditions in wintertime.

Both energy costs and more stringent requirements regarding air emissions are driving forces for energy efficiency for ship operation and also in shipbuilding. Design and selection of materials will also affect the environmental impact, e.g. from dust emissions when ships are repaired and the selection of coating will affect the frequency and method of hull treatment. 
There is a lot of research ongoing in this field. Promising areas of the research that can assist in meeting the goals include, for example:

- Developments for eco-efficient design of hull reducing resistance and combining antifouling properties; viscous resistance reduction identifying new laminar hull concepts; wave-ship motion optimisation; advanced hull designs for inland and shallow water navigation; and next generation propulsors.

- Lightweight and higher strength composite materials.

- Combustion optimisation of marine engines (injection timing, compression ratio, fuel spray geometry, etc.); alternative fuels (LNG, methanol, ethanol, DME, biodiesel and biogas); renewable energy propulsion (wind, sea and solar power); fuel cells running on hydrogen as auxiliary propulsion power; and, in a longer-term vision, a diverse fuel mix adoption, with LNG, biogas, batteries and hydrogen produced from renewable sources.

Design for the environment in new shipyard construction is an efficient way to minimise emissions. New docks and slipways shall be constructed to allow wastewater to be collected for treatment. 


\section{BAT at shipyards}

BAT at shipyards is overall described in this Chapter. Specific BAT candidates, which are selected as the most relevant to consider in preventing emissions and impacts are described in more detail in the next Chapter.

Environmental impacts from shipyards, but also possibilities to mitigate the impacts, are very much case dependent for a number of reasons. The KEI and reasons for different environmental impacts in different situations were discussed in the previous chapter.

\subsection{BAT for environmental management, including monitoring and reporting}

- The staff must understand the importance of correct routines and procedures such as in handling of chemicals and waste and shall work accordingly. This is achieved through the commitment of management and regular training.

- Have a system to monitor and calculate emissions and how to report emissions based on a "log book system".

- Possible historical contamination shall be taken into account in dredging and excavation works or if operations end both at land and sea. Soil or sediment shall be investigated beforehand and, if contamination is found, treated adequately.

\subsection{BAT for control of air emission}

- Minimise dust in dry blasting by enclosing activities when possible. Dry blasting can take place either inside a hall, or tent or curtains can be used in outdoor blasting. The risk for particulate emissions is greatest in open operations exposed to wind. In windy weather, dry blasting outdoors needs to be stopped. Dust and fumes from the hall shall be collected and treated with a cyclone or filter.

- Minimise dust by wet blasting, such as UHP blasting instead of dry blasting when possible. Wet blasting does not work well in very cold weather. 
- Substitute traditional solvent-based paints with low-VOC or solvent-free paints or non-chemical treatments, when possible. Nevertheless, several limitations on their application and also economics need to be considered. In practice, substitution can be difficult, even impossible. Also cross-media effects and life cycle need to be carefully assessed. If surface treatment is done with good quality and proper methods and paint, unnecessary docking and surface treatment is avoided overall.

- Selection of paints and quality assurance often take place by ship owner or paint manufacturer based on corrosion protection, appearance, antifouling and warranty requirements for specific purposes. A shipyard selects paints only in a few cases. Therefore, the possibilities to control VOC emissions by shipyards are limited.

\subsection{BAT for noise emissions}

- Noise emission is reduced if working under the dock edge is possible.

- Use noise shields where possible.

- Conduct noise measurement and identify significant noise sources and potential sensitive receptors in the vicinity and reduce noise when necessary. Capsulation is a way to reduce noise (in situation of a new shipyard or if operations change).

- Obey occupational health and safety limits for noise. Use personal protective equipment when needed.

\subsection{BAT for control of wastewater and stormwater emissions}

- Remove paint residues, leftovers etc. from the dock before flooding.

- Remove pollutants and environmentally harmful materials frequently from docks, especially materials which can be moved by the wind or be mixed up with stormwater.

- Have designed surfaces (even and undamaged) making collection and cleaning of abrasives, removed paints, oils etc. possible and effective.

- Have methods to collect and clean abrasives, removed paints, oils etc. and procedures how to do it.

- Have a barrier against direct drainage of wastewater and stormwater to the harbour or sea. 
- Collect and treat, when possible, all wastewater and stormwater streams from areas that have the potential for being contaminated. Only clean stormwater can be discharged into surrounding environment as untreated. For example, use sedimentation and buffer tanks to treat wastewater and reduce content of solids.

- Use sand filter and oil separator at a minimum.

- Combine sedimentation tanks with oil separator, sand and carbon filter where there is a risk of emission of pollutants exceeding the emission limit values. Nevertheless, several limitations on application and economics need to be considered in particular at old shipyards where even efficient collection of all wastewater can be challenging.

\subsection{BAT for chemicals handling and substitution}

- Control and optimised consumption of chemicals.

- Use less harmful chemicals when possible.

- Follow the duties of downstream user of chemicals related to the safe handling and use of chemicals according to the provisions set in the safety data sheets. For example, personal protective equipment (gloves, eye protection etc.) shall be available and used by workers handling hazardous materials.

\subsection{BAT for waste management and minimisation}

- Recycle dry blasting material when possible.

- Source separate different waste fractions and do not mix wastes.

- Reuse, recycle and recover waste when possible.

- Waste shall be delivered only to permitted vendors.

- Store waste in designated, labelled containers in sheltered and roofed areas in order to avoid spread of waste into environment, for example leakage of chemicals into soil or spread of dust by wind.

- Specific requirements apply for storage and handling of hazardous waste including metals, solvents etc. 


\subsection{BAT for reduction of risks and accidents}

- Appropriate risk management procedures and trained personnel shall be in place.

- An embankment of chemical storages shall have the capacity to retain all chemicals in case of leakage or accident.

- $\quad$ Adequate spill kits, fire extinguishers and other emergency provisions and procedures shall be in place (for example a valve to close sewer lines in case of emergency). There shall also be a plan to ensure firewater does not get into environment in a case of a fire.

- Inspect embankment and safety equipment regularly.

- Follow fire and chemical regulations in storage and handling of paints and solvents. Explosion proof documents shall be in place.

\subsection{BAT for design and construction}

- Consider the entire life span of the ship, its energy consumption, recyclability of the materials etc. in ship design.

- New docks and slipways shall be constructed to allow wastewater to be collected for treatment.

\subsection{BAT for energy management}

- Identify possibilities for energy saving, including the optimisation of electrical power supply and consumption, energy efficient equipment, influencing the behaviour of the organisation and employees to save energy, etc.

- Fouling significantly increases vehicle drag resulting in reduced speed, higher energy consumption and even damage of ship. 


\section{BAT Candidates}

The shortlisted BAT candidates described in this chapter were chosen according to the following priorities:

- $B A T$, which addresses the identified Key Environmental Indicators.

- BAT, which is assessed to have a significant reduction of emission and impacts.

- BAT, which is economically and technically viable taking into consideration the cost and advantages.

- BAT, which primarily is developed or has its origin in the Nordic countries.

The technical and economic applicability of BAT candidates differs a lot case-by-case as described under each BAT candidate. It is also noteworthy that the selection of techniques is not always in the hands of the shipyard. The ship owner or paint manufacturer often determine the surface treatment and coating requirements.

Table 8: Shortlisted BAT candidates

\section{No. BAT title Key Environmental Indicator}

Ultra High Pressure water blasting (UHP blasting)

Air emissions, waste and noise

Low-VOC paints

Air emissions

Solvent-free paints

Air emissions

Waterbased paints in shipbuilding

Wastewater and air emission

Fully or partially enclosed facilities for surface treatment

Air emissions and noise

Multi-functional wastewater treatment facilities

Wastewater

Environmental Management Systems (EMS)

Wastewater and air emission

Environmental friendly construction and operation of docks

Paint container

Wastewater and noise

Environmental friendly underwater hull and propeller cleaning

Waste

Wastewater, air emissions and noise 


\subsection{BAT Candidate no. 1 - Ultra High Pressure water blasting (UHP blasting)}

\subsubsection{Introduction}

Different wet blasting methods are used as an alternative to dry blasting to prevent or reduce the dust emission from surface treatment.

UHP blasting is a dustless surface treatment method using extremely high pressure, water and no abrasive. There are also methods that combine use of water with an abrasive.

For example, in Norway the majority of ship repair yards use UHP or other wet blasting methods, whereas dry blasting is considered too expensive and time consuming. In Finland, only one shipyard uses UHP blasting. There are also many doubts that UHP blasting is not suitable for all purposes and conditions. It appears that the applicability and overall economics need to be assessed case specifically depending on various factors.

\subsubsection{Applied processes and techniques}

UHP blasting typically uses a water pressure at 3000 bar (800-3000 bar depending on the model).

UHP blasting is generally considered a fast method compared to traditional dry blasting. Treatment efficiency for UHP blasting can be several times faster (20-30 $\mathrm{m}^{2} / \mathrm{h}$ up to $350 \mathrm{~m}^{2} / \mathrm{h}$ depending on the model) than traditional dry blasting $\left(4-5 \mathrm{~m}^{2} / \mathrm{h}\right)$. Estimates vary a lot and depend on various site-specific factors and thus can be considered only as indicative.

One advantage of UHP is that water penetrates deep into the metal pores allowing an efficient removal of chlorides, much more efficiently than in dry blasting. Also poorly adhering coating is efficiently removed in UHP since water forces its way through and under the coating, breaking the bond and shearing it off.

In advanced UHP models, for example Hammelmann's Dockmaster or Spiderjet or Den-Jet's different models, the work is carried out remotely. The nozzle is attached to the work surface by vacuum, which at the same time sucks off the removed waste material and wastewater. The wastewater is treated before discharge or it can be filtered and reused and the sludge can be collected into bags.

The nozzle can furthermore be encapsulated in a box, which further reduces the noise. Use of a robot also minimises the health and safety risks of blasting. This is also an important issue since conditions can be extreme outdoors and in confined spaces such as inside tanks. Shipyard employees are at an increased risk of exposure to toxic 
dusts, high noise levels, and a range of other safety and health hazards. Yet it is noteworthy that if UHP is used manually, specific safety clothing is needed because of the extremely high pressure.

Figure 10: UHP blasting operated manually at Alfons Håkans Oy repair yard in Suomenlinna (the right picture) and remotely with sludge collected (Hammelmann in the left picture)

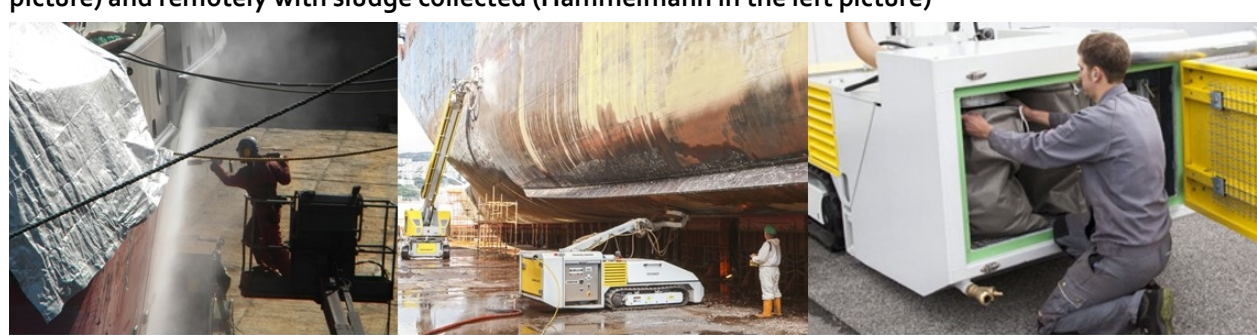

\subsubsection{Emission and consumption figures}

No emission data are available at present. Emissions are very much case specific.

An example of maximum emission values for wastewater substances from highand low-pressure washing ("tvätt") are given in the environmental approval of Falkvarv in Sweden in Table 9.

Table 9: An example of maximum emission values for wastewater sub-stances from high- and lowpressure washing ("tvätt") in the environmental approval of Falkvarv in Sweden (2008)

Substances Max. emission values

$\begin{array}{lc}\mathrm{Pb} & 3 \mu \mathrm{g} / \text { litre } \\ \mathrm{Cr} & 15 \mu \mathrm{g} / \text { /itre } \\ \mathrm{Cd} & 0.3 \mu \mathrm{g} / \text { /itre } \\ \mathrm{Cu} & 9 \mu \mathrm{g} / \text { litre } \\ \mathrm{Ni} & 45 \mu \mathrm{g} / \text { litre } \\ \mathrm{Zn} & 60 \mu \mathrm{g} / \text { litre } \\ \text { Mineral oil (oil index) } & 5 \mu \mathrm{g} / \text { litre } \\ \text { TBT } & 0.001 \mu \mathrm{g} / \text { litre } \\ \text { TOC } & 10 \mathrm{mg} / \mathrm{litre}\end{array}$

When using UHP blasting, the amount of waste material to be disposed of can be $1 / 100$ as compared to dry blasting. 


\subsubsection{Environmental benefits}

UHP blasting has several environmental advantages. No abrasives are used and dust formed of paint residues is bound in water, which minimises dust and waste production. Only paint waste needs to be collected and disposed of safely.

Generally, noise is comparable to traditional dry blasting methods, whereas in advanced models noise is efficiently reduced by vacuum or use of a box around the spear head.

Water consumption is small, typically $10 \ldots 20 \mathrm{l} / \mathrm{min}$. When using a robot, also the wastewater may be collected directly in tanks. In some models, water can be collected, filtered and reused, which also means easy separation of waste for controlled disposal.

Figure 11: Box around the spear head in some more advanced robot models further reduces noise (Picture from Den-Jet)

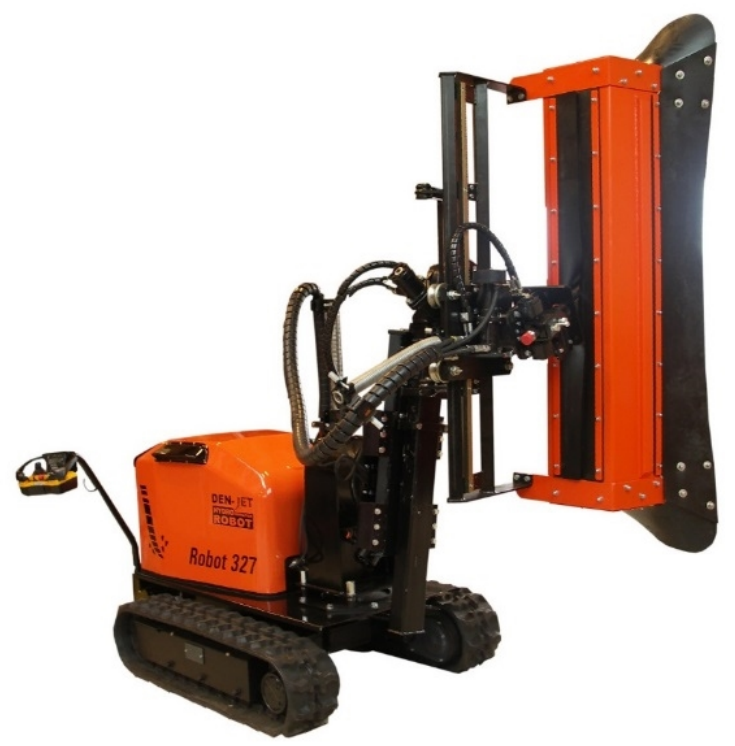

\subsubsection{Applicability}

UHP and other wet blasting methods are replacing traditional dry blasting as shipyard operators get good experiences of these technologies. The technologies have both technical and environmental advantages over traditional dry blasting as described above. 
The efficiency of UHP varies case by case but is generally considered better over traditional dry blasting. A Finnish shipyard has made a comprehensive study to compare UHP and traditional blasting methods and has ended up using UHP (Peled 2013).

Nevertheless, opinions on UHP vary a lot among shipyard operators. There are also strong doubts that UHP blasting is not suitable for all surfaces and conditions. UHP water blasting is not applicable in cold climate conditions, below $-5^{\circ} \mathrm{C}$. Furthermore, UHP blasting is not creating the same rough surface as dry blasting methods, which is necessary for the following surface treatment processes. Therefore, the technology is generally not applicable for new surfaces. Some repair yards and their clients claim that this limits applicability of UHP also in repair yards. One of the shipyards contacted has commented that their clients demand to use paints that is not applicable with UHP as pre-treatment method. A paint manufacturer, on the other hand, states that for most purposes a paint can be found suitable with UHP. Applicability of UHP together with specific coating needs to be verified from the paint supplier and usually it also must be approved by the client.

One of the shipyards contacted has commented that grit-blasting with water injection gives the best result in regard to surface, but in particular to cost. One of the shipyards has informed that a current challenge in UHP blasting is that the nozzles in UHP need to be very small to enable personnel to carry it out with hand-held devices. The robot versions currently on the market, on the other hand, are not versatile enough to be applicable for the sometimes small vessels and limited square metres to be blasted.

\subsubsection{Cross-media effect}

None.

\subsubsection{Economics}

The disadvantage of UHP blasting is higher investment and maintenance costs as compared to traditional methods (investment costs and maintenance costs are double or more as compared to traditional methods). Some shipyards consider UHP blasting more economic than traditional techniques, some not. Many case-dependent factors affect the overall costs, labour time, waste management costs etc. In particular, waste management costs can be significantly higher in dry blasting as compared to UHP. The amount of waste material to be disposed of can be $1 / 100$ as compared to dry blasting. As described earlier in Chapter 4.5 , consumption of blasting media in traditional blasting can be $40-50 \mathrm{~kg} / \mathrm{m}^{2}$ when in UHP only removed paint and rust is pro- 
duced as solid waste, typically $0.5 \mathrm{~kg} / \mathrm{m}^{2}$. Waste management costs can vary from tens of euros per tonne up to hundreds of euros per tonne depending on whether the waste can be recovered as material or needs to be disposed of as hazardous waste.

\subsubsection{Reference}

- Den-Jet, Denmark.

- Hammelmann / Hammeli Oy, Finland.

- Contacted shipyards and suppliers.

- Peled 2013.

\subsection{BAT Candidate no. 2. - Low-VOC paints}

\subsubsection{Introduction}

Paint manufacturers have been able to develop paints containing less VOCs than earlier. Traditional paints have a typical VOC content of $50 \%$. Today paints that have a lower VOC content of typically $30 \%$ or less ("low-VOC paints") are widely used in the Nordic countries.

\subsubsection{Applied processes and techniques}

Painting with low-VOC paints usually takes place with ordinary wet spraying equipment.

\subsubsection{Emission and consumption figures}

Using low-VOC paints, VOC emissions can be significantly reduced compared to traditional paints. VOC content of low-VOC paints varies, being typically $30 \%$ or less.

\subsubsection{Environmental benefits}

VOC emissions are reduced and heating of the painting environment is rarely needed. 


\subsubsection{Applicability}

No significant limitations.

\subsubsection{Cross-media effect}

None.

\subsubsection{Economics}

Low-solvent paints are typically somewhat more expensive than conventional solvent-based paints, but are widely used in the Nordic countries.

5.2.8 Reference

- Nor-Maali.

- Visited and contacted shipyards.

\subsection{BAT Candidate no. $3-$ Solvent-free paints}

\subsubsection{Introduction}

At the moment, solvent-free paints have limited application possibilities at repair yards. A typical use is for icebreakers.

\subsubsection{Applied processes and techniques}

Solvent-free paints are more difficult to work with as compared to traditional paints, as they are more rigid in their structure. Also hardening time is typically longer. Typically, solvent-free 2-component coatings are applied using heated spray guns. Heating is needed to make the paint smoother and easier to apply. 


\subsubsection{Emission and consumption figures}

Paint VOC emissions are reduced using solvent-free paints. On the other hand, solvent-free paints can only be used in conditions above $+10^{\circ} \mathrm{C}$. Heating is usually needed for applying the paint.

\subsubsection{Environmental benefits}

VOC emissions are reduced compared to the use of traditional paints.

\subsubsection{Applicability}

Solvent-free paints typically require a minimum temperature of $+10^{\circ} \mathrm{C}$. For example, in Finland during the winter months the temperature does not rise above $+10^{\circ} \mathrm{C}$ degrees and the use of solvent-free paints would require much heating.

Application possibilities can be limited. For example, at the Ornskov Shipyard in Denmark, only $3-5 \%$ of all painting work is done with solvent-free paint. Similar figures were reported also at other shipyards.

\subsubsection{Cross-media effect}

If heating is required, indirect emissions occur from the energy consumed to heat up the application equipment and sometimes to increase the temperature in the painting environment during winter months.

\subsubsection{Economics}

Solvent-free paints are typically more expensive than traditional or low-VOC paints. Heating the spraygun and painting environment increases costs.

\subsubsection{Reference}

- Nor-Maali.

- Visited and contacted shipyards. 


\subsection{BAT Candidate no. 4- Waterborne paints in shipbuilding}

\subsubsection{Introduction}

Waterborne paints are commonly used in shipbuilding for painting the internal premises of ships. However, they have limited or no application possibilities in the exterior surfaces and in repair and maintenance.

\subsubsection{Applied processes and techniques}

Painting with waterborne paints usually takes place with ordinary wet spraying equipment.

\subsubsection{Emission and consumption figures}

VOC emissions can be significantly reduced when solvent-based paints are replaced by waterborne paints in interior painting. Typical waterborne paints contain also small amounts of VOCs, but the emissions are insignificant when compared to solventbased paints.

\subsubsection{Environmental benefits}

VOC emissions are reduced and workers are not exposed to solvents.

\subsubsection{Applicability}

Waterborne paints can principally be used only in the internal premises of ships. Waterborne paints cannot be applied in cold temperatures. Usually they require a minimum temperature of $+10^{\circ} \mathrm{C}$ during painting.

\subsubsection{Cross-media effect}

Waterborne painting requires heating in winter conditions, which produces air emissions from combustion. 


\subsubsection{Economics}

Waterborne paints are mainly used in internal premises and usually interior paints are less expensive than exterior paints. Heating the painting environment increases costs.

\subsubsection{Reference}

- Nor-Maali.

- Visited and contacted shipyards.

\subsection{BAT Candidate no. 5 - Fully or partially enclosed facilities for surface treatment}

\subsubsection{Introduction}

Enclosement of facilities for surface treatment enables better control of environmental impacts, dust in dry blasting, fumes and noise. Another advantage is that weather conditions do not affect work that much.

In Norway, a large number of small and medium-sized repair yards (handling vessels with LOA 15-90 $\mathrm{m}$ ) have invested in production halls covering slipways and dry docks. In Finland, there is also one small, fully-covered repair yard.

Also partial and temporary enclosement is possible using tents or curtains.

\subsubsection{Applied processes and techniques}

Different applications are possible: a hall or tent or curtains. 
Figure 12: Examples of partial (picture from Turku Repair Yard Ltd) and fully closed working environment (picture from Skarvik AS internet pages)
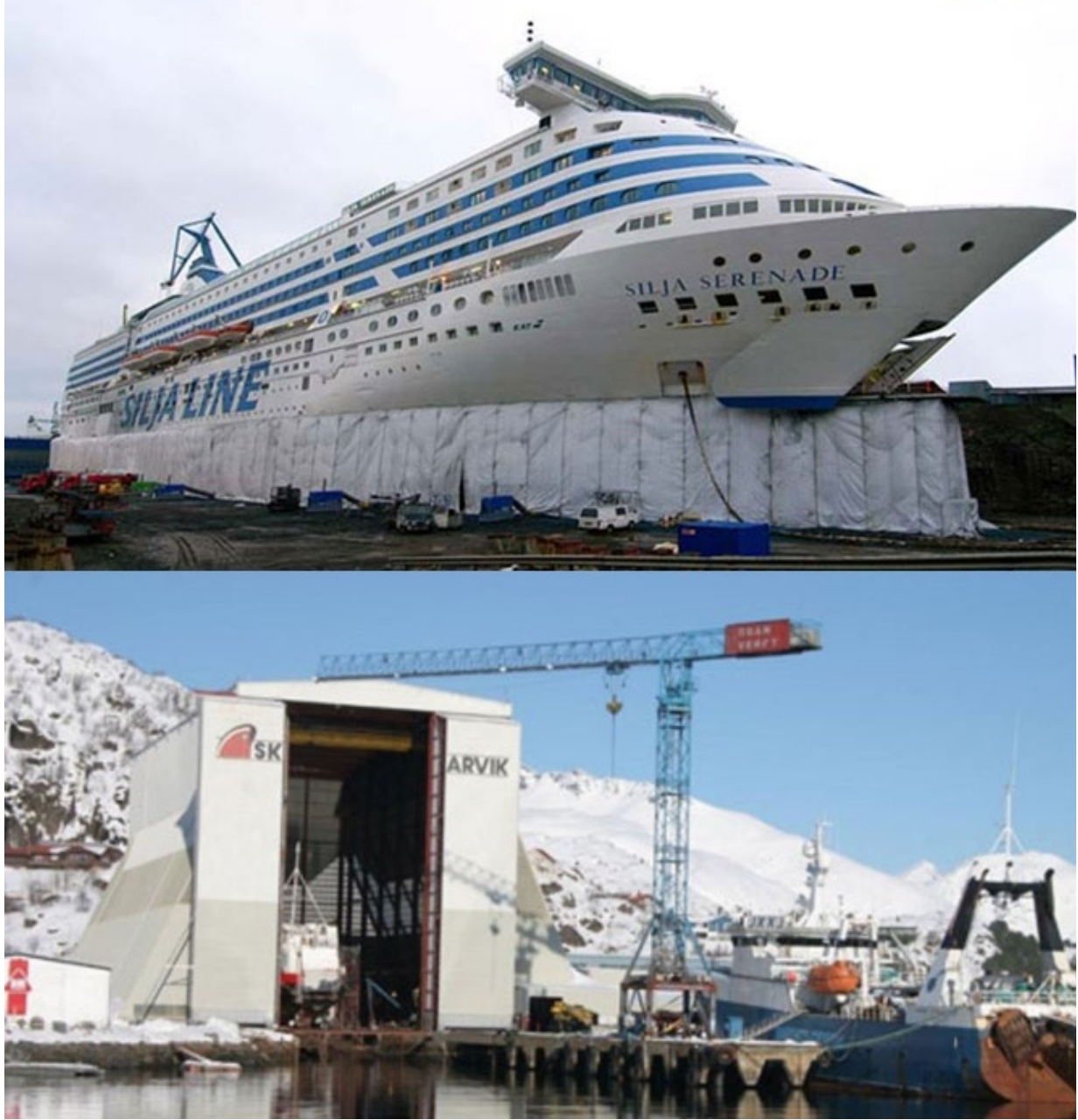

\subsubsection{Emission and consumption figures}

No information. 


\subsubsection{Environmental benefits}

By enclosing the working environment, removal of particles from the extracted air streams becomes possible. Enclosement may also reduce noise emission.

\subsubsection{Applicability}

It is possible to build a hall for a small or medium-size shipyard covering the slipway or dry dock. Inside a hall, surface treatment is possible in all weather conditions. Also partial and temporary enclosement is possible using tents or curtains.

In shipbuilding, typically several unit operations take place in halls.

\subsubsection{Cross-media effect}

Enclosement of operations minimises environmental impacts assuming that the dust and fumes are collected and treated adequately. Otherwise dust and fumes can be an occupational health and safety risk indoors.

Energy is needed for air extraction.

\subsubsection{Economics}

A drawback of enclosement is the high price. The cost of surface treatment inside a temporary tent may cost more than double compared to traditional open-air surface treatment.

A hall easily costs from one to several millions of euros.

\subsubsection{Reference}

Discussions with shipyards. 


\subsection{BAT Candidate no. 6 - Multi-functional wastewater treatment facilities}

\subsubsection{Introduction}

Wastewater from shipyards is managed differently in the different Nordic countries. Also the amount and characteristics of wastewater vary a lot depending of various factors: type of shipyard and operations and techniques as well as environmental conditions. The amount of wastewater is much higher if the shipyard is exposed to rain,. A challenge for a multistep wastewater treatment can be significant variation in both flow and characteristics of the wastewater.

Some shipyards are discharging wastewater to the public or municipal sewer system and others have their own wastewater treatment facilities, like using an oil separator, sand filters, flocculation and settling chambers. Small shipyards can simply have a sump that is emptied regularly. Some small, old shipyards have no possibility to efficiently collect wastewater, but most of it filtrates into soil or flows to the sea.

Typical components of shipyard wastewater - oil and heavy metals - are a problem both when discharging wastewater to the public or municipal sewer system or directly to the sea.

Only a limited number of shipyards in the Nordic countries (e.g. in Denmark) are using advanced multi-functional wastewater systems. Such a system could contain an initial settling chamber, a band filter, and in some cases also a combination of a sand filter with a carbon filter to effectively remove all kinds of pollutants from the wastewater. Combined systems will effectively remove all pollutants, like oil, grease, heavy metal and biocides from ship paints. The drawback of advanced wastewater treatment facilities is high investment and operating costs, in particular if installed in an old shipyard where even efficient collection of all wastewater can be challenging. Furthermore, multi-functional wastewater treatment facilities require skills and competences to operate and maintain them efficiently.

\subsubsection{Applied processes and techniques}

An efficient multi-functional wastewater treatment plant for handling wastewater from surface treatment activities in shipyards can be constructed as a combined system with a settling chamber, band filter, sand and carbon filter. Such an arrangement will reduce concentrations of all pollutants significantly and below the allowed emission limit values (see under section "Emission and consumption figures"). It is note- 
worthy that often wastewater treatment plants do not include all these components but can include only some of the unit operations.

A schematic illustration of an example of such a combined system is shown in Figure 13 .

Figure 13: Schematic illustration of a multi-functional wastewater treatment unit

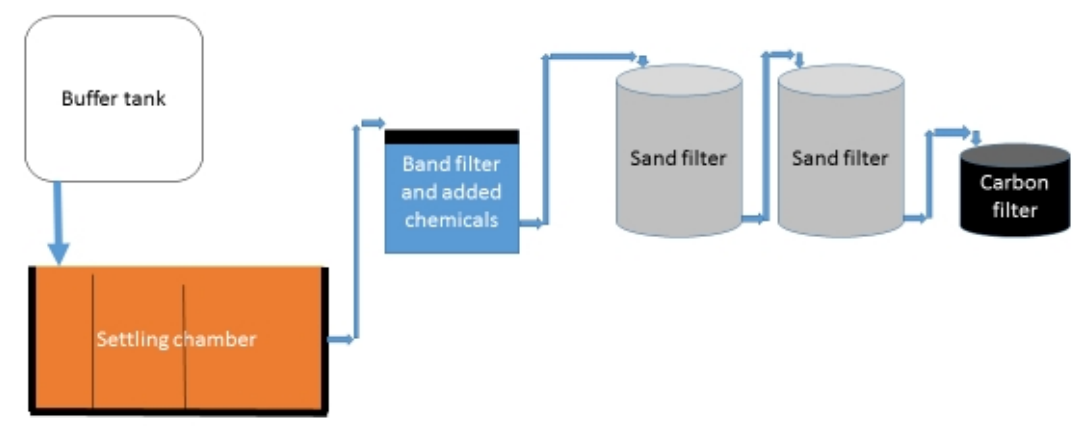

Oil and grease will be removed before the settling chamber by an oil separator, if the retention time is sufficient. A buffer tank can be used to adjust the flow to the settling chamber in peak situations.

Flocculation agents are added in the band filter to allow flocks to form and larger particles to settle or be removed in the sand filter. The flocculation agents can also be added before the settling chamber.

These filtration steps will remove a great deal of the heavy metals in the wastewater as they will react with the flocculation agent. The sand filter (could be a double tank system) consists of quartz sand and must be back-washed from time to time to remove the filter cake. The sludge must be collected and handled according to safe sludge handling procedures.

The final carbon filter will remove the rest of the organic pollutants, like organic biocide etc.

Wastewater facilities can be installed indoors or as floating facilities, like at the Oresund shipyard in Landskrona. 
Figure 14: Multifunctional filter arrangement (Picture from internet pages of Danish Water Solutions Industry)
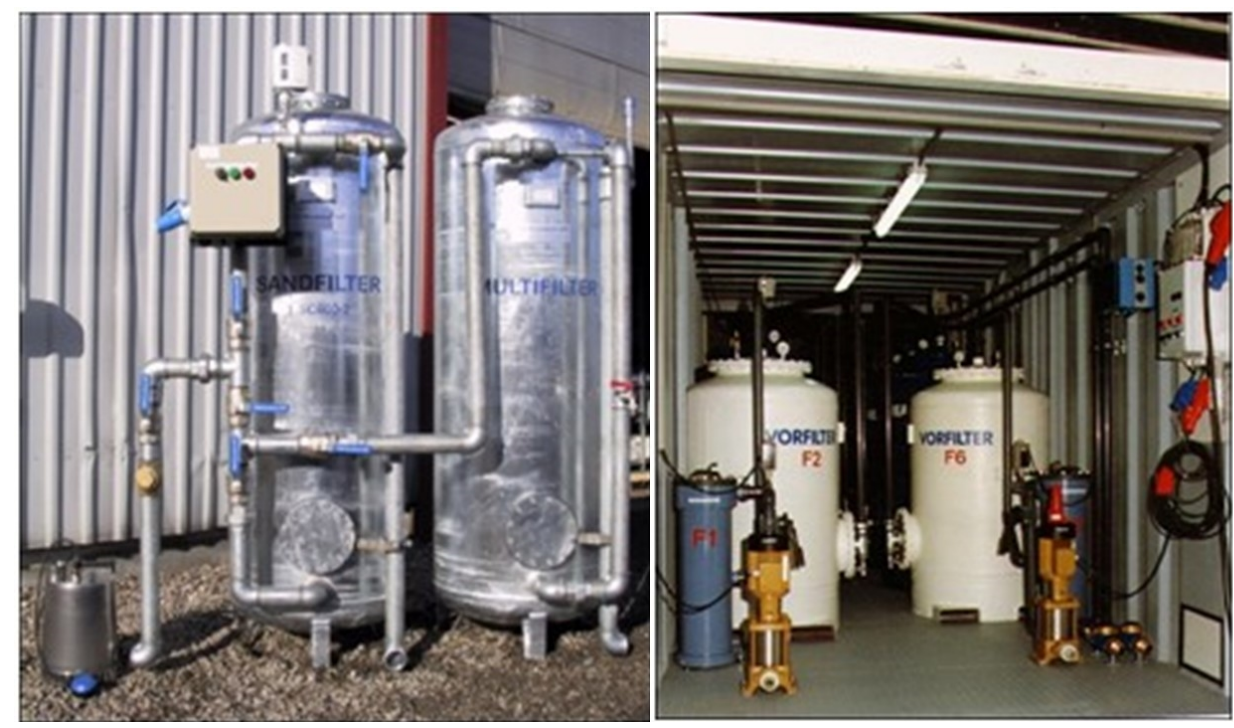

\subsubsection{Emission and consumption figures}

Examples of maximum wastewater emission values of heavy metals and oil from docks at Fayard Shipyard to Odense Fjord, Denmark are shown in Table 10.

Table 10: An example of wastewater emission values of heavy metals and oil from docks at Fayard Shipyard to Odense Fjord, Denmark (2009)

\begin{tabular}{lc} 
Substances & Max. emission values from Fayard Shipyard to Odense Fjord \\
$\mathrm{Pb}$ & $28 \mu \mathrm{g} /$ litre \\
$\mathrm{Cr}$ & $5 \mu \mathrm{g} / \mathrm{litre}$ \\
$\mathrm{Cu}$ & $14.5 \mu \mathrm{g} / \mathrm{litre}$ \\
$\mathrm{Ni}$ & $41.5 \mu \mathrm{g} / \mathrm{itre}$ \\
$\mathrm{Zn}$ & $430 \mu \mathrm{g} / \mathrm{litre}$ \\
Mineral oil & $20 \mathrm{mg} / \mathrm{litre}$ \\
$\mathrm{TBT}$ & \\
TOC & \\
\hline
\end{tabular}




\subsubsection{Environmental benefits}

The multi-functional wastewater treatment solution with several treatment steps will effectively remove the concentration of pollutants below existing threshold limit values.

\subsubsection{Applicability}

Wastewater treatment of a shipyard plant can be improved by changes in practices and equipment in operation and upgrade of monitoring and control systems and by end-of-pipe treatment, meaning actual wastewater treatment. The preferred option should always be to find out the possibilities for the shipyard's internal measures for reducing the wastewater amount and load, such as dry collection of waste. Upgrade of wastewater treatment shall be considered only secondarily when the desired results are not achieved by internal measures. Issues to consider include technical issues, such as flow and load variations, the investment in the appropriate spaces, desired treatment result, set limits and authority and municipality requirements, and investment and operating costs including handling of sludge. See also the Chapter "Environmentally friendly construction and operation of docks".

The described wastewater solution might in principle be applicable to all shipyards in the Nordic countries. However, a drawback of advanced wastewater treatment facilities is high investment and operating costs, in particular if installed in an old shipyard where even efficient collection of all wastewater can be challenging. Operating costs include labour costs, electricity, chemical costs, waste management costs, etc. Furthermore, multi-functional wastewater treatment facilities require skills and competences to operate and maintain efficiently. When it comes to use at very low temperatures and in snowy weather conditions the equipment need to be indoors, which further increases costs. A challenge for a multistep wastewater treatment is typically significant variation in both flow and characteristics of the wastewater. This is important to take into account in the wastewater treatment process design.

It is also noteworthy that often wastewater treatment plants do not include all these components but can include only some of the unit operations.

\subsubsection{Cross-media effect}

Wastewater filtration systems will produce highly concentrated and hazardous sludge, which has to be handled according to environmental guidelines given by the environmental authority. Usually it is necessary to dewater sludge at least to $15-20 \%$ dry solid content for transport economy and disposal. 


\subsubsection{Economics}

The cost of a wastewater treatment plant depends very much on the number of treatment steps included and the amount of wastewater. A wastewater treatment plant such as the multifunctional system described could amount to a hundred thousand euros up to several hundred thousands of euros (Ref.: Norwegian Maritime Branch, 2012).

Also operational costs are relatively high when the process has several steps, often tens of thousands of euros per year.

When the wastewater discharge costs go up for a shipyard, it will reach a breakthrough, when it will be more attractive to establish a wastewater treatment at the shipyard. This is an alternative to collection and transport of the wastewater over a long distance to a municipal wastewater treatment plant.

\subsubsection{Reference}

- Norweigian Industry, Maritime Branch, 2012.

- Danish Water Solutions Industry A/S, Slagelse, Denmark (closed according to the home page of the company).

\subsection{BAT Candidate no. 7 - Environmental Management Systems (EMS)}

\subsubsection{Introduction}

The staff must understand the importance of correct routines and procedures such as in handling of chemicals and waste and shall work accordingly. A certified or noncertified EMS is a tool to systematise and monitor these routines and procedures. Many of the largest shipyards have an EMS certified according to ISO14001, which typically consists of:

- An environmental policy.

- Planning and implementation of procedures including maintenance of equipment.

- Monitoring and control of environmental performance.

- Initiating corrective measures.

- Conducting of internal and external audits. 
EMS of a shipyard shall consist of components like monitoring, calculation and reporting of emissions (maintaining a logbook) of environmental parameters relevant for the shipyard, as well as monitoring of maintenance routines. Shipyard shall maintain a logbook documenting the incoming and outgoing fluxes of environmental pollutants, like VOCs, potential amounts of biocide in paints etc., as well as a log of changing air filters and calibrating $\mathrm{pH}$ meters. The discharge concentrations can consequently be documented and reported if required in an environmental permit or upon request from the environmental authority.

Emission of the discharge of water from, for example, water blasting can be calculated from data for the area treated, the volume of water and the average known concentration of pollutants in the paints. Every ship shall have a logbook descriping the used type of paints and their thickness. Data can in many cases be submitted by the shipping company or the shipyards responsible for the previous surface treatment.

For example, in Denmark, shipyards have in their environmental permit a possibility to avoid wastewater treatment, if they can document that the concentrations of pollutants in wastewater comply with wastewater emission standards. This information can be collected by sampling and analysis or by calculations.

\subsubsection{Applied processes and techniques}

Calculation of a mass balance for VOC and corresponding VOC reduction plan is a typical requirement from shipyards in environmental permit and shall also be part of EMS. This allows estimation of the diffuse emsission, which cannot be measured. Known sources are subtracted from the input data and then the diffuse emission including also dust is estimated.

As another example, environmental monitoring and reporting can be applied for the purpose to document that outdoor surface treatment is only taking place when windspeed and wind direction are within accepted limits. The documentation takes place by use of official metereological data, which is combined with an activity logbook of surface treatment activities in the docks.

Monitoring and regular maintenance of pollution prevention equipment are prerequisite for efficient management of air emissions as well as wastewater emissions.

Internal control and maintenance of a logbook for activities in the docks is a commonly used technique and often also a requirement in environmental permit to document the environmental performance of the activities. The following activities must as a minimum be included in the logbook: 
- Timing of docking in and out of ships.

- Methods used for surface treatment.

- Quantities and types of paints used.

- Timing of surface treatment activities.

- Preventive measures applied, including enclosure of activities.

- Maintenance of equipment for pollution prevention and control.

\subsubsection{Emission and consumption figures}

No data available at present.

\subsubsection{Environmental benefits}

The techniques and measures described under EMS will create awareness on the environmental impacts of the activities, which will reduce the emsissions. Furthermore, the techniques will make it possible to document the environmental impacts.

In principle, the first step in reducing emissions is to become aware of them.

\subsubsection{Applicability}

The methods described are aplicable to all shipyards.

\subsubsection{Cross-media effect}

Not applicable.

\subsubsection{Economics}

Not analysed.

\subsubsection{Reference}

Oresund Shipyard, Landskrona, Sweden 


\subsection{BAT Candidate no. 8 - Environmentally friendly construction and operation of docks}

\subsubsection{Introduction}

New docks and slipways shall be established with a system to collect and handle dry waste effectively and keep it separate from wet waste. Furthermore, they shall establish a system to separate wastewater from stormwater and run-off water.

\subsubsection{Applied processes and techniques}

Frequent cleaning of the surfaces around a ship's bottom containing environmentally harmful biocides must be applied.

Figure 15: Typical equipment to collect dry blasting materials from docks (Bobcat, Pictures from Dae-Tek Oy)

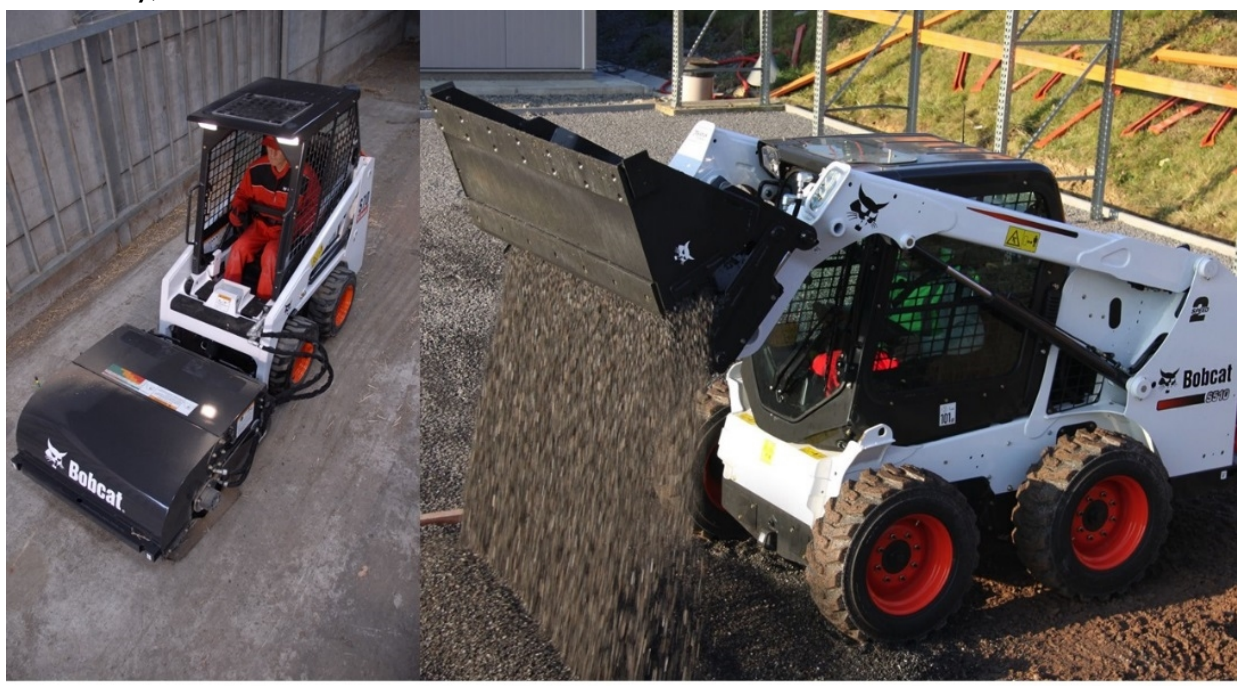

Such a procedure will allow the stormwater to be discharged directly to the recipient waterbody without cleaning if it is not polluted or via a wastewater treatment facility.

Ideally, all docks must slope towards a wastewater collection channel equipped with barriers allowing the operator to control if the water must be treated or it can be discharged to the sea. 
The docks shall be equipped with pumps at seaside to empty the docks and for discharge of stormwater to the sea. At landside there must be pumps to manage the wastewater for treatment.

\subsubsection{Emission and consumption figures}

Heavy rainfall can easily produce a much larger volume of wastewater than wastewater from surface treatment of ships. Consequently, a system to separate stormwater and wastewater shall be implemented.

\subsubsection{Environmental benefits}

The environmental benefits of having a dock constructed and operated as described above are that the emissions of pollutants to the sea are eliminated or reduced.

\subsubsection{Applicability}

The most cost-effective approach is to include environmental considerations, when new docks are designed and constructed and when larger changes or reconstruction take place. Upgrading of existing and older docks may be complicated and expensive.

\subsubsection{Cross-media effect}

Not analysed.

\subsubsection{Economics}

Not analysed.

\subsubsection{Reference}

Dae-Tek Oy. 


\subsection{BAT Candidate no. 9-Paint containers}

\subsubsection{Introduction}

Traditionally paints are provided from paint manufacturers and used at shipyards in $20 \mathrm{I}$ containers. Instead of canisters, paints can be delivered from paint manufacturers in larger containers, which reduce waste (no empty metal containers containing paint residues).

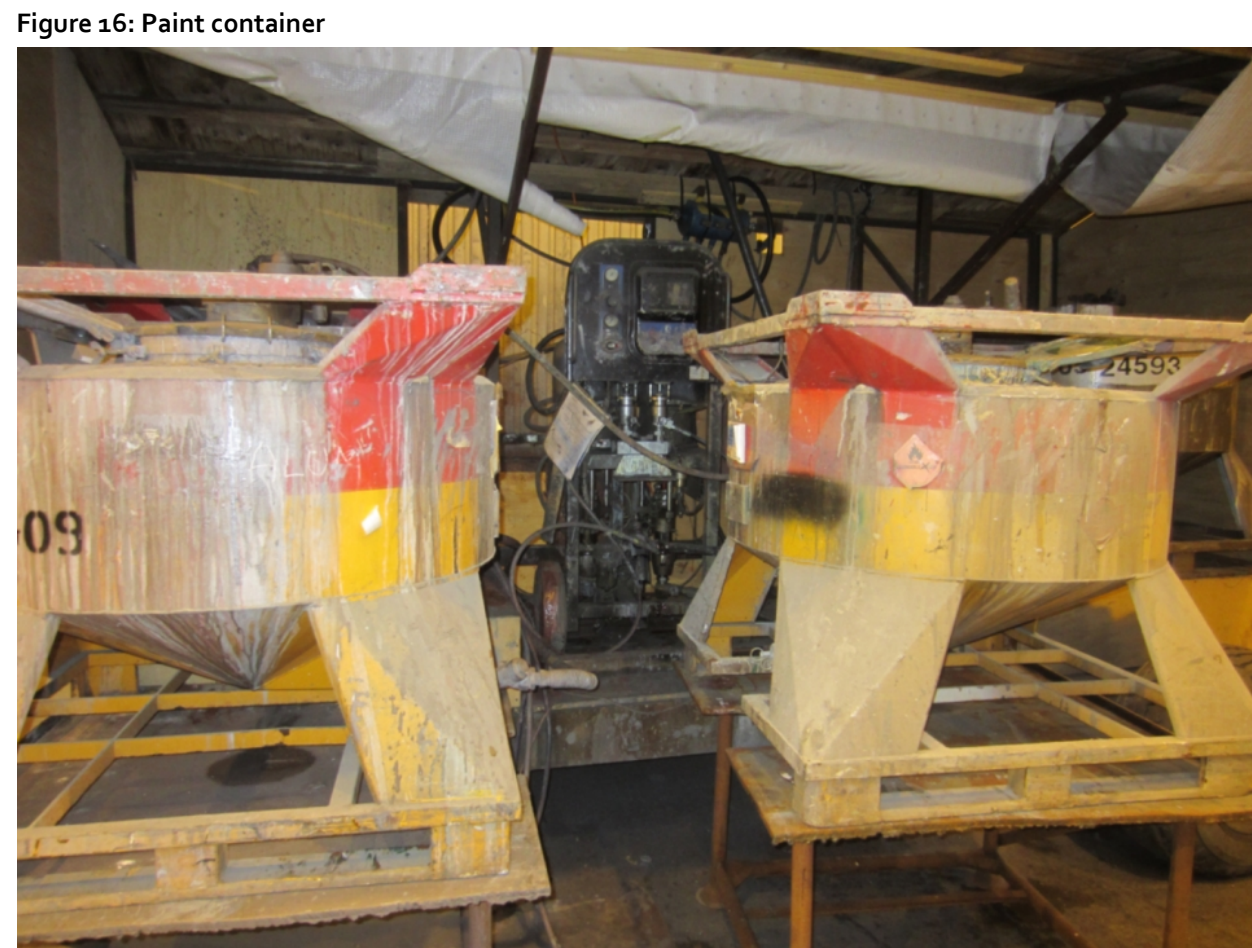

\subsubsection{Applied processes and techniques}

Instead of small canisters, paints can be delivered from paint manufacturers in containers. Spray pistols are connected directly to the container.

When 2-component paints are used, the mixing of paints takes place by means of a precise dosage system and no extra solvents are needed. 


\subsubsection{Emission and consumption figures}

Not analysed in more detail.

\subsubsection{Environmental benefits}

There is less need for manual work and no empty metal containers containing paint residues. VOC emissions are reduced.

\subsubsection{Applicability}

Paint manufacturers provide paints in 500,800 and 1000 I containers. If such an amount of paint is used and containers are readily available, this is an environmentally and economically sound solution. Sometimes these containers can be too large for the quantities consumed in smaller shipyards.

\subsubsection{Cross-media effect}

None.

\subsubsection{Economics}

Not analysed.

5.9.8 Reference

- Nor-Maali.

- Arctech

5.10 BAT Candidate no. 10 - Environmentally friendly underwater hull and propeller cleaning

\subsubsection{Introduction}

The presented technology to clean and maintain the hull and propeller of ships and vessels is developed to be used underwater and to be operated in harbours or at anchor to save costly time in docks. The cleaning system is in most cases operated by water pres- 
sure and rotating polypropylene brushes. The equipment is able to remove marine fouling and reactivate the existing antifouling system applied to the ship hull when previously painted. There is another similar Finnish application, DG Green cleaning system. Both the technologies have environmental approvals to operate in Nordic harbors, for example the harbour of Copenhagen.

\subsubsection{Applied processes and techniques}

The technology is developed and continuously improved with a hull cleaning machine with curtains preventing pollutants from escaping a filter system. The system is operated by a diver using mounted video camera and lights to document the results. The vacuum allows the cleaning machine to be kept tight to the treated surface (hydraulic pressure is $10 \mathrm{bar} / 1,000$ I per minute in one application). The equipment is working with water pressure. It sucks the removed marine fouling and used water through a filter arrangement before discharging them to the sea.

Figure 17: A diver in action with the cleaning machine. (pictures from Mermaid Marine Service Aps)

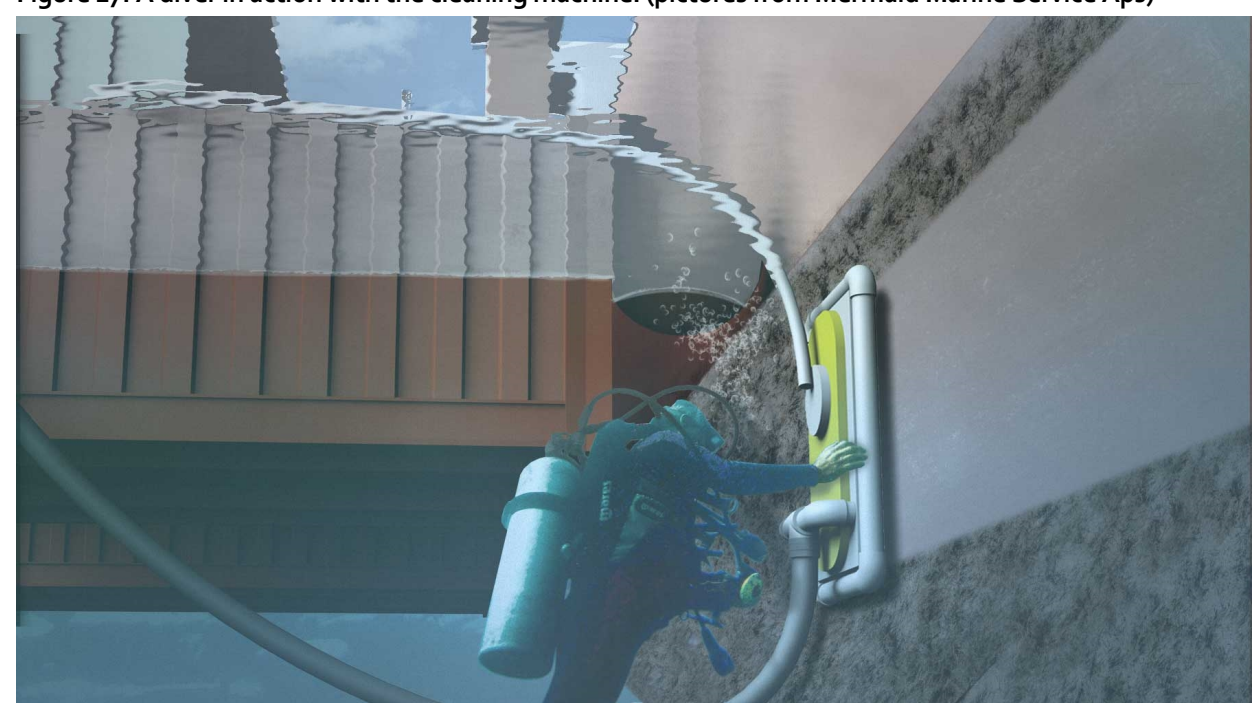

Seawater is used to develop the pressure. The machine is supplied with a hose to collect the wastewater for treatment.

The filter system has changeable filters suitable for the present paints and marine fouling system. Before any operations are launched, a dye trace test is completed to ensure the pressure is working and the water is sucked to the wastewater treatment 
system. The brushed off fouling will be retained in the filter bags, while the cleaned water flows back into the sea.

When the filters are replaced, the used filter bags are kept in waterproof containers. When the hull cleaning is completed, the filter bags will be delivered to the local waste handling plant. The waste handling plant will receive information about the fouling and a copy of the vessel's antifouling certificate, enabling the treatment plant to dispose of the filter bags according to local environmental regulation.

The equipment contains a number of brushes (often two or three) designed for the job, the fouling to be removed and the paint system applied. The pressure and the water flow direction can be changed.

Figure 18: Illustration of both sides of and with brushes under the cleaning machine (pictures from Mermaid Marine Service Aps)

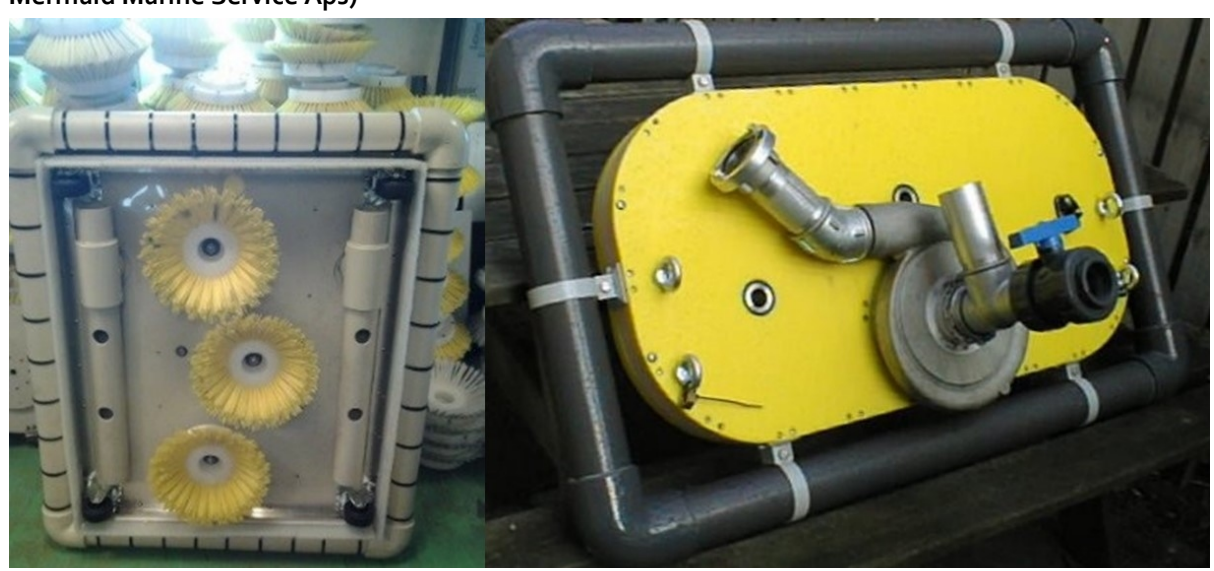

\subsubsection{Emission and consumption figures}

The Mermaid's hull and propeller technology and the emissions from its use are tested by laboratory analysis. Based on the documentation an environmental approval is temporarily issued by Copenhagen Municipality and is valid for one year at a time. The environmental authority of Copenhagen has granted the Mermaid Marine Service approval to operate in the Harbour of Copenhagen under specified conditions and with surface areas up to $2,800 \mathrm{~m}^{2}$ per ship. The company must manage an internal control system and report quarterly to the authorities on the number of treated ships and vessels, treated area and the quality of the discharged wastewater.

Samples are taken before and after the filter and a sample $10 \mathrm{~m}$ from the discharge point of cleaned wastewater to document the level of emissions of hazardous substances to the sea. Heavy metals are removed from the hull during the cleaning 
activity and removal of marine fouling. The amount of heavy metals removed depends very much on the antifouling system applied.

The results from laboratory analysis from May 2015 are given in Table 11 (reference: Mermaid).

\begin{tabular}{|c|c|c|c|}
\hline Substances $(\mu \mathrm{g} / \mathrm{l})$ & Before filter & After filter & $10 \mathrm{~m}$ from machine \\
\hline Suspended solids & 700 & 9.4 & 4.9 \\
\hline As (Arsenic) & 8 & 0.97 & 0.96 \\
\hline $\mathrm{Pb}$ & 15 & 0.20 & 0.043 \\
\hline $\mathrm{Cd}$ & 0.3 & 0.021 & 0.019 \\
\hline Ba (Barium) & 47 & 10 & 10 \\
\hline $\mathrm{Cu}$ & 210 & 1.8 & 0.66 \\
\hline $\mathrm{Ni}$ & 12 & 0.60 & 0.63 \\
\hline Sr (Strontium) & 3 & 2 & 2 \\
\hline $\mathrm{Zn}$ & 730 & 6.5 & 2.4 \\
\hline
\end{tabular}

Please note that the sensitivity of the recipient differs between harbours due to water flow, exchange rates etc. Consequently, the emission limit values in different harbours might differ as well.

\subsubsection{Environmental benefits}

The hull cleaning technology will reduce the need and the frequency for blasting of ships saving water, energy and reducing potential emissions to the environment by traditional blasting methods.

All hull cleaning machines are water driven and therefore there is no risk of oil spills as may occur during treatment with oil hydraulic machines.

\subsubsection{Applicability}

The methods can be applied to all kinds of ships and both sides of the ships can be treated with the same equipment.

\subsubsection{Cross-media effect}

The Mermaid Marine Company is claiming that up to $23 \%$ of the fuel (and the same reduction of $\mathrm{CO}_{2}$-emission) can be saved (reduced) by using this cleaning and maintenance method. The saving depends on the paint system used and the age of the ship. 
The oil prices will reflect the interest from potential customers and number of contacts to the company. Low oil prices as they are at the moment will reduce the market for cleaning of hulls and propellers.

\subsubsection{Economics}

The method is a very fast treatment of hulls and the speed depends on the type of marine fouling and the applied paint system. $20 \mathrm{~m}^{2} / \mathrm{min}$ or $1,200 \mathrm{~m}^{2} /$ hour can be treated by light marine fouling.

Mermaid Marine Service is informing on their web-page that it costs 3.5 USD per $\mathrm{m}^{2}$ for light to medium fouling, including collection of waste materials.

5.10.8 References

- Mermaid Marine Service Aps.

- Municipality of Copenhagen, Water team.

- DG Green cleaning system. 



\section{Emerging techniques}

Emerging techniques are BAT not yet fully developed or in use in the industry, although they may be relevant as BAT candidates in the future.

\subsection{Paint removal from ship hull by induction heating by laser}

\subsubsection{Introduction}

There is a recognised method for removal of paint and coatings on steel surfaces by induction heating by laser. This is a potential alternative to abrasive blasting and UHP water. The technology is at the moment cost competitive and used for thick coating layers. For example, the US Navy is one user of the system in a number of shipyards in the USA.

\subsubsection{Applied processes and techniques}

Controlled induction is used to heat the steel surface so that the coating debonds and can easily be removed. This technology is especially efficient on thick paints and coatings.

\subsubsection{Emission and consumption figures}

No data available at present.

\subsubsection{Environmental benefits}

Benefits of the technology include:

- Faster removal rate on thick, difficult coatings as compared to abrasive blasting and UHP. 
- Less energy consumed than abrasive blasting and UHP.

- Minimal emissions and noise.

- Safer for the operator.

\subsubsection{Applicability}

The technology is used, for example, on bridges, offshore installations, steel construction, storage tanks, pipes and marine ships. 
Figure 19: Induction heating equipment (pictures from RPR Technologies)

How does it work?
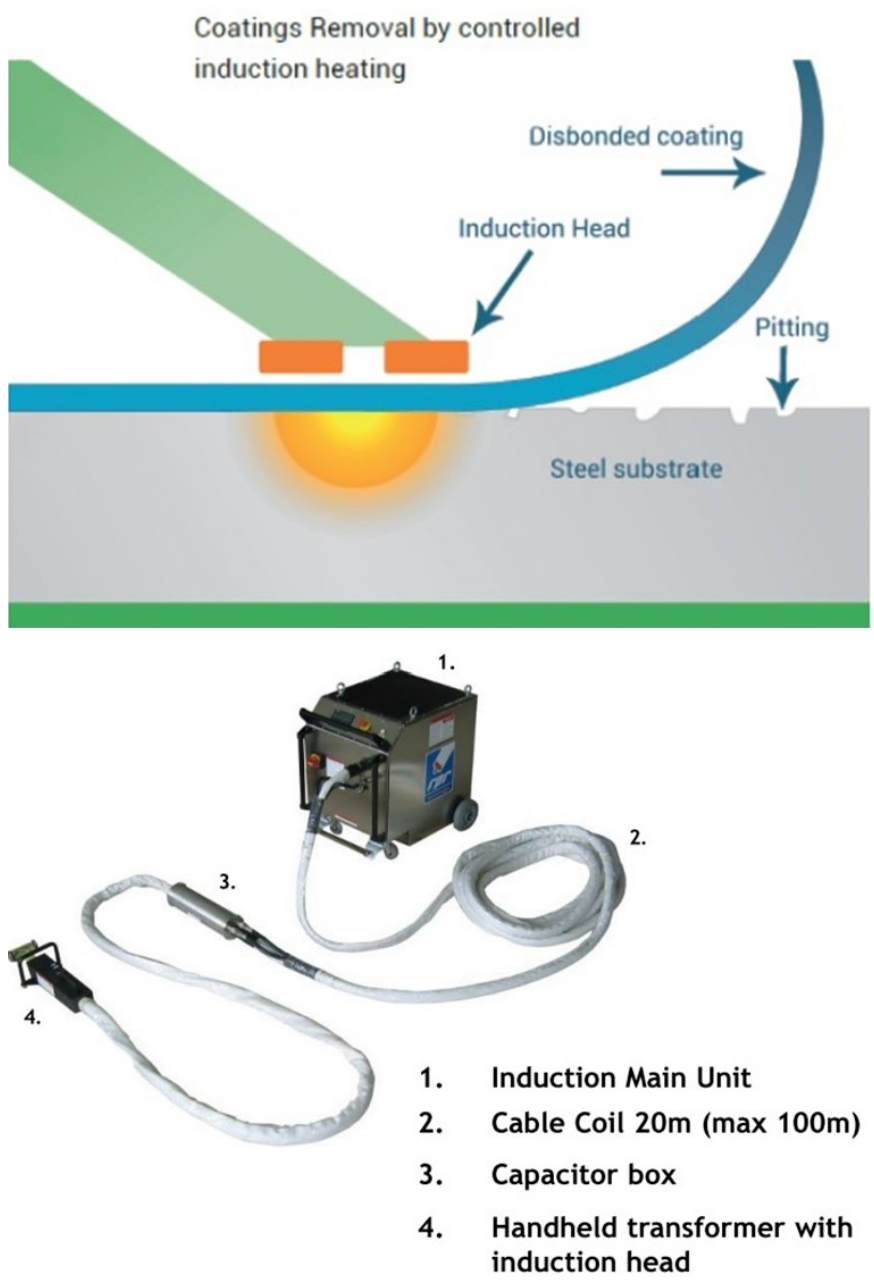

6.1.6 Cross-media effect

No data available at present. 


\subsubsection{Economics}

The technology is at the moment cost competitive for thick coating layers. The investment cost is higher compared to other technologies.

6.1.8 Reference

RPR Technologies. 


\section{References and contacts}

Alfons Håkans Oy, visit and contact with Tero Hänninen.

Arctech Helsinki Shipyard Oy, visit and contact with Ari Sylve.

Dae-Tek Oy, contact with Marko Kierros.

Danish Water Solutions Industry A/S, Slagelse, Denmark.

DG Green cleaning system, Internet pages http://dg.fi/site/service/cleaning/, contact with Jarno Kalliomäki

ELY-centralen i Egentliga Finland, contact with Esa Wihlman.

European Commission, Reference Document on Best Available Techniques on Surface Treatment using Organic Solvents, 2007.

European Energy Innovation, Internet pages:

http://www.europeanenergyinnovation.eu/Articles/Spring-2014/Energy-Efficient-Shipping-

And-Impact-On-Shipbuilding-Evolution

Falkvarv AB, contact with Niklas Engholm.

Finnish marine industries, Internet pages: http://meriteollisuus.teknologiateollisuus.fi and contact with Merja Salmi-Lindgren

Hammeli Oy, contact with Åke Rundberg.

International Labour Office (ILO), Workplace Health and Safety Information, Internet pages: http://www.ilocis.org

Länstyrelsen Hallands Län, Fastställande av slutlika villkor I tillstånd enligt miljöbalken till varvsverksamhet på fastigheten Varvet 1, Falkenbergs kommun, 2008.

Mermaid Marine Service Aps, Internet pages www.hullcleaningequipment.com

Meyer Turku Oy, visit and contact with Jaana Hänninen.

Miljødirektoratet, Norge, Regulering av forurensning fra skipsverft: Miljødirektoratets veileder til fylkesmannen. M-487 Veileder, 2016.

Miljødirektoratet, Norge, Miljøkrav for skipsverft. Faktaark M-496, 2016.

Miljøstyrelsen Danmark, Overfladebehandling af skibe, Vejledning Nr. 3., 1991.

Ministry of the Environment of Finland, Guidance on dredging and disposal of dredged sediment, 2015.

m/s Tähti, Internet pages http://tahtilaiva.blogspot.fi/2015/11/paijanteen-telakka.html

Municipality of Copenhagen, contact with the Water team.

Navidom Oy, contact with Sami Niemelä.

Nor-Maali Oy, visit and contact with Petri Hirvensalo.

Nordic Council of Ministers, Reduction of emissions from Ship Yards, Tema Nord 1996:556, 1996.

Nordic Council of Ministers, Best Available Technique: Buller från bergtäkter, TemaNord, 2013:588. 
Nordisk Minsiterråd, Hvordan begrense forurensing fra små skipsverft? Fakta om forurensing fra små skipsverft, 2011.

Norsk Industri, Beste praksis for miljøarbeid i skipsverft - utslipp og avfall, 2012.

Norsk Industris bransjeforeninger for Maritim, contact with Tor Andersen.

Nylands Miljöcentral, Environmental permit for Aker Yards Oy, 2008.

Nylands Miljöcentral, Environmental permit for Suomenlinna repair yard, 2008.

Närings-, trafok- och miljöcentralen i Norra Savolax, Contact with Kimmo Koistinen.

Peled B., Development of the environmental safety of shipyard's maintenance painting (in Finnish), Master of Science Thesis, Tampere University of Technology, 2013.

Pulli, J., Heikkilä, J. \& Kosomaa, L., Designing an environmental performance indicator for shipbuilding and ship dismantling. Project ECO-EFFI Final Report, Turku University of Applied Sciences, 2013.

Päijänteen Telakka Oy, visit and contact with Jukka Kauppi.

Regionförvaltningsverket i Södra Finland, Environmental permit for Päijänteen Telakka Oy, 2013.

RPR Technologies, Internet pages http://www.rprtech.com/, contact with Tommy Gabe.

Sibelco Nordic, Safety Data sheet of Nickel Slag, 2011.

Skarvik AS, internet pages http://www.skarvik.no/

Stálsmiðjan-Framtak.

Stockholms Reparationsvarv AB, contact with Gustav Löwing.

Sydvästra Finlands Miljöcentral, Environmental permit for STX Finland Cruise Oy, 2008 (current Meyer Turku Oy).

Sydvästra Finlands Miljöcentral, Environmental permit for Turun Korjaustelakka Oy, 2009.

Swedish Maritime Technology Forum, contact with Karina Linnér.

Turku Repair Yard Ltd, visit and contact with Juha Olli.

Ålands miljö- och hälsoskyddsmyndighet, Environmental permit for Algots Varv Ab, 2013. 


\section{Sammenfatning}

Nordisk Ministerråds BAT Gruppe har ønsket gennemført et project om Bedst Tilgængelige Teknikker (BAT) for skibsværfter i de nordiske lande. Formålet med opgaven har været at:

- Gennemføre et review og beskrive skibsværftssektoren i de nordiske lande.

- Gennemføre et review og beskrive de anvendte teknikker i sektoren.

- Identificere og beskrive centrale miljøindikatorer fra et nordisk perspektiv.

- Identificere og beskrive teknikker, som skal være indeholdt i de betragtninger, der repræsenterer BAT på skibsværfter.

Afgrænsningen af dette project har været stålskibsværfter, men ikke skibe bygget i træ eller forstærket plastic. Fokus har været på overfladebehandling i forhold til vedligeholdelse og reparation, men også i mindre udstrækning til skibsbygning. Ophugning, håndtering af ballastvand og motorreparationer har ikke været omfattet af projektet.

De beskrevne informationer og oplysninger i rapporten kan anvendes af skibsværfter, miljøkonsulenter og miljømyndigheder i landene. Projektets resultater vil muligvis også kunne anvendes som et nordisk input til den Tekniske Arbejdsgruppe for revisionen af BAT konklusionerne på BREF-en for "Surface Treatment Using Organic Solvents (STS)" i henhold til Industrial Emission Directive (IED-direktivet).

Skibsbygning har en lang tradition og har tidligere været en betydelig industrisektor i de nordiske lande. I dag har de nordiske lande primært reparations- og vedligeholdelsesværfter. På den anden side så foregår der nybygningsaktiviteter på et begrænset antal værfter i de nordiske lande.

Miljøpåvirkningerne fra skibsværfter i de nordiske lande er meget forskellige. Især er der stor forskel på nybyggeri og reparations- og vedligeholdelseaktiviteter. Der er flere grunde hertil:

- Skibsværfter har meget forskellige faciliteter og størrelser, såsom dokker, flydedokker og beddinger, hvilket giver forskellige muligheder for at begrænse emissionerne. Nogle skibsværfter er ældre og har derfor ikke udstyr med de 
samme muligheder for at begrænse emissioner som nye værfter (f.eks. barrierer og spildevandsfaciliteter). Moderne udstyr kan være besværligt eller dyrt at installere på ældre værfter.

- Skibenes størrelser er forskellige.

- De nordiske lande har meget forskellige klimatiske betingelser (temperatur, tidevand, snevejr m.v.).

- Værfternes placeringer (nogle værfter ligger i byer og tæt på beboelse eller ligger $\mathrm{i}$ naturbeskyttelsesområder).

De centrale miljøpåvirkninger behandlet i denne rapport er i ikke-prioriteret rækkefølge:

- Luft emissioner (støv og VOC).

- Støj emission.

- Emissioner fra spilde- og overfladevand (sundhedsskadelige stoffer som tungmetaller og olie).

- Affaldsfraktioner (stål i skibsbygning, slibemidler med sundhedsskadelige stoffer for vedligeholdelse og reparationer)

- Kemikalier (maling og anti-begroningsmidler).

- Forureninger ledt til jord, grundvand og hav- og søvand og sedimenter.

- Energieffektivitet og miljøvenligt design.

De beskrevne BAT på skibsværfter omfatter beskrivelser af:

- BAT for miljøledelse, inklusiv monitering og rapportering.

- BAT for kontrol af udledningen af luftforureninger.

- BAT for støjemission.

- BAT for kontrol af udledningen af spilde- og overfladevand.

- BAT for håndtering og substitution af kemikalier.

- BAT for affald management og minimering.

- BAT for reduktion af risici og ulykker.

- BAT for design og etablering af værfter.

- BAT for energiledelse. 
De tekniske og økonimiske forhold såvel som miljøpåvirkningen af BAT varierer meget og er i mange tilfælde afhængig af, hvilken BAT der vurderes. Det er i den forbindelse værd at bemærke, at valget af BAT altid ligger hos skibsværftet. Rederiet og malevareleverandøren bestemmer dog ofte, hvilke malevaresystemer, der skal anvendes samt hvilket udstyr, der skal anvendes som forbehandling ved skibets overfaldebehandling. Rapportens beskrevne BAT kandidater er vist i tabel 12.

\section{Tabel 12: BAT kandidater}

\section{Nr. \\ BAT kandidate}

Ultra højt vandtryks blæsning (UHP blæsning)

Maling med lavt VOC indhold

Opløsningsmiddelfrie malinger

Vandbaserede malinger til skibsbygning

Helt eller delvist indkapslede faciliteter til overfladebehandling

Multifunktionelle spildevandsbehandlingsfaciliteter

Miljøledelsessystemer

Miljøvenlig konstruktion og drift af dokker

Malevare containere

Miljøvenlig skibsskrog-og propelrensning

Fjernelse af maling fra skibsskrog ved induktionsopvarmning med laser gennemgås som en spirende teknologi. Der finds ikke viden om, at denne teknologi anvendes på nordiske værfter i dag. De eksisterende teknologier anvendes i dag til forskellige specialopgaver for at fjerne overfladebeskyttelse, især tykkere lag. 
Nordic Council of Ministers

Ved Stranden 18

DK-1061 Copenhagen K

www.norden.org

\section{Nordic Shipyards}

The Nordic Council of Ministers, the BAT Group under the Working Group for Sustainable Consumption and Production (also called HKP Group) awarded Vahanen Environment Oy, Finland, together with COWI AS, Denmark to prepare a Best Available Techniques (BAT) project on shipyards in the Nordic countries. The objectives of the project have been to:

- review and describe the shipyard sector in the Nordic countries

- review and describe the used techniques in the Nordic countries

- identify and describe the Key Environmental Indicators from the Nordic perspective

- identify and describe techniques that shall be included in the considerations of representing BAT in shipyards.

The scope of the project has included steel ships. The main focus has been on surface treatment in relation to maintenance and repair.

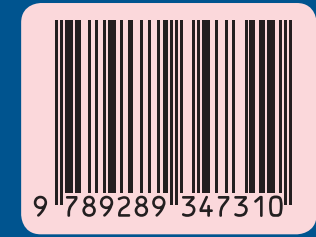

